\title{
Experimental investigation and application of the equilibrium rutile + orthopyroxene $=$ quartz + ilmenite
}

\author{
Jodie L. Hayob ${ }^{1 *}$, Steven R. Bohlen ${ }^{2}$, and Eric J. Essene ${ }^{1}$ \\ ${ }^{1}$ Department of Geological Sciences, University of Michigan, Ann Arbor, MI 48109-1063, USA \\ ${ }^{2}$ U.S. Geological Survey, 345 Middlefield Rd., Menlo Park, CA 94025, USA
}

Received December 14, 1992 / Accepted May 20, 1993

\begin{abstract}
Equilibria in the Sirf (Silica-Ilmenite-RutileFerrosilite) system:

$\mathrm{SiO}_{2}+(\mathrm{Mg}, \mathrm{Fe}) \mathrm{TiO}_{3}=\mathrm{TiO}_{2}+(\mathrm{Mg}, \mathrm{Fe}) \mathrm{SiO}_{3}$
\end{abstract}

have been calibrated in the range $800-1100^{\circ} \mathrm{C}$ and $12-$ $26 \mathrm{kbar}$ using a piston-cylinder apparatus to assess the potential of the equilibria for geobarometry in granulite facies assemblages that lack garnet. Thermodynamic calculations indicate that the two end-member equilibria involving quartz + geikielite $=$ rutile + enstatite, and quartz + ilmenite $=$ rutile + ferrosilite, are metastable. We therefore reversed equilibria over the compositional range $\mathrm{Fs}_{40-70}$, using $\mathrm{Ag}_{80} \mathrm{Pd}_{20}$ capsules with $f_{\mathrm{O}_{2}}$ buffered at or near iron-wüstite. Ilmenite compositions coexisting with orthopyroxene are $X_{\mathrm{MgTiO}_{3}}^{\mathrm{Ilm}}$ of 0.06 to 0.15 and $X_{\mathrm{Fe}_{2} \mathrm{O}_{3}}^{\mathrm{llm}}$ of 0.00 to 0.01 , corresponding to $K_{D}$ values of $13.3,10.2,9.0$ and $8.0( \pm 0.5)$ at $800,900,1000$ and $1100^{\circ} \mathrm{C}$, respectively, where $K_{D}=(X \mathrm{Mg} / X \mathrm{Fe})^{\mathrm{opx}} /$ $(X \mathrm{Mg} / X \mathrm{Fe})^{\mathrm{Ilm}}$. Pressures have been calculated using equilibria in the Sirf system for granulites from the Grenville Province of Ontario and for granulite facies xenoliths from central Mexico. Pressures are consistent with other well-calibrated geobarometers for orthopyroxeneilmenite pairs from two Mexican samples in which oxide textures appear to represent equilibrium. Geologically unreasonable pressures are obtained, however, where oxide textures are complex. Application of data from this study on the equilibrium distribution of iron and magnesium between ilmenite and orthopyroxene suggests that some ilmenite in deep crustal xenoliths is not equilibrated with coexisting pyroxene, while assemblages from exposed granulite terranes have reequilibrated during retrogression. The Sirf equilibria are sensitive to small changes in composition and may be used for determination of activity/composition $(a / X)$ relations of orthopyroxene if an ilmenite model is specified. A symmetric regular solution model has been used for orthopyroxene in conjunction with activity models for ilmenite available

\footnotetext{
* Present address: Department of Environmental Science and Geology, Mary Washington College, Fredericksburg, VA 22401-5358, USA

Correspondence to: J.L. Hayob
}

from the literature to calculate $a / X$ relations in orthopyroxene of intermediate composition. Data from this study indicate that $\mathrm{FeSiO}_{3}-\mathrm{MgSiO}_{3}$ orthopyroxene exhibits small, positive deviations from ideality over the range $800-1100^{\circ} \mathrm{C}$.

\section{Introduction}

Orthopyroxene is common in igneous rocks and in metamorphic rocks of the granulite facies. It is an important phase for many thermobarometers such as the garnetplagioclase-orthopyroxene-quartz barometer (Newton and Perkins 1982; Bohlen et al. 1983a; Eckert et al. 1991), the ferrosilite-fayalite-quartz barometer (Bohlen and Boettcher 1981) and the garnet-orthopyroxene exchange thermometer (Harley 1984; Sen and Bhattacharya 1984; Lee and Ganguly 1988; Eckert and Bohlen 1992). To obtain accurate estimates of pressures and temperatures from these equilibria, knowledge of the activity/composition $(a / X)$ relations of orthopyroxene is important.

The Sirf (Silica-Ilmenite-Rutile-Ferrosilite) system can be defined by three equilibria. The first two involve mass transfer in the pure iron and magnesium systems. A third, studied experimentally by Bishop (1980), involves exchange of iron and magnesium between orthopyroxene and ilmenite.

$$
\begin{array}{rlc}
\text { Rutile }+\mathrm{Ferrosilite}= & \text { Quartz }+\mathrm{Ilmenite} \\
\mathrm{TiO}_{2}+\mathrm{FeSiO}_{3} & =\mathrm{SiO}_{2}+\mathrm{FeTiO}_{3} \\
\text { Rutile }+\mathrm{Enstatite} & = & \text { Quartz }+ \text { Geikielite } \\
\mathrm{TiO}_{2}+\mathrm{MgSiO}_{3} & =\mathrm{SiO}_{2}+\mathrm{MgTiO}_{3} \\
\text { Ferrosilite }+\mathrm{Geikielite}= & \text { Enstatite }_{\text {Ilmenite }} \\
\mathrm{FeSiO}_{3}+\mathrm{MgTiO}_{3} & \mathrm{MgSiO}_{3}+\mathrm{FeTiO}_{3}
\end{array}
$$

We have calibrated the Sirf equilibria over a range of pressures, temperatures and compositions and have used the results to estimate pressures of equilibration for granulite facies assemblages and to determine $a / X$ relations in orthopyroxene. In all calculations, a single formula unit $\left(\mathrm{RSiO}_{3}, R=\mathrm{Fe}^{2+}, \mathrm{Mg}\right.$ ) will be assumed for orthopyroxene unless otherwise specified. Locations of the Sirf 
equilibrium (1) for $\alpha$-quartz and coesite were calculated from the Tweeq program of Berman (1991) and the thermodynamic data set of Berman (1988) (Fig. 1). Equilibrium (1) involving $\alpha$-quartz is metastable with respect to coesite, and equilibrium (1) involving coesite is metastable because of the transition of rutile to $\mathrm{TiO}_{2}-\mathrm{II}$, a high pressure polymorph (Akaogi et al. 1992). The magnesium end-member (2) is located in negative pressure space and it is metastable with respect to the equilibrium: rutile + enstatite $=$ quartz $+\mathrm{MgTi}_{2} \mathrm{O}_{5}$ (not shown). Also shown in Fig. 1 are the breakdown reactions for ferrosilite, rutile + ilmenite and rutile + geikielite. Although thermodynamic calculations imply that equilibria (1) and (2) are metastable in the Sirf system, rutile is stable with inter-

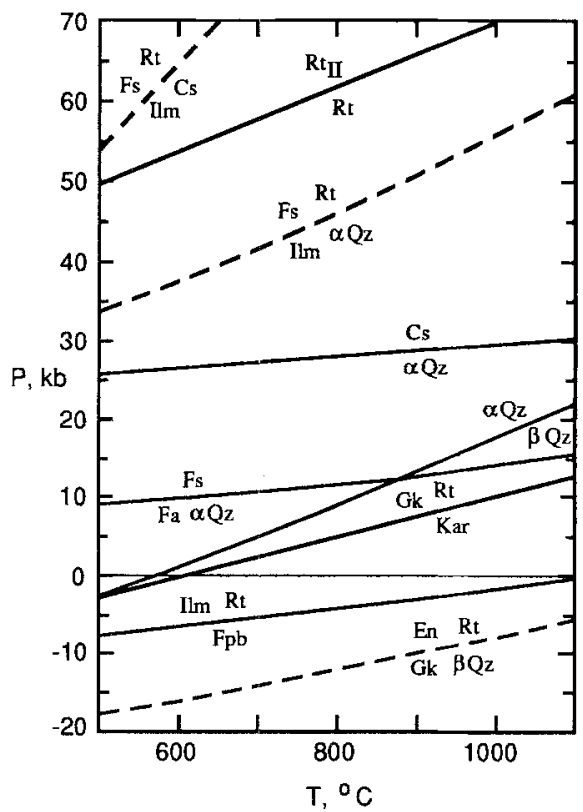

Fig. 1. Pressure-temperature diagram showing loci of end-member equilibria in the system $\mathrm{FeO}-\mathrm{MgO}-\mathrm{TiO}_{2}-\mathrm{SiO}_{2}$ calculated from the data set of Berman (1988). Polymorphic transitions involving oxides are: $\alpha \mathrm{Qz}=\beta \mathrm{Qz}$ (Cohen and Klement 1967), $\alpha \mathrm{Qz}=\mathrm{Cs}$ (Bohlen and Boettcher 1982), and $\mathrm{Rt}=\mathrm{Rt} \mathrm{t}_{\mathrm{II}}$ (Akaogi et al. 1992). The equilibria: $\mathrm{Fs}=\mathrm{Fa}+\alpha \mathrm{Qz}$ (Bohlen et al. 1980), Gk $+\mathrm{Rt}=\mathrm{Kar}$ (Lindsley et al. 1974) and $\mathrm{Ilm}+\mathrm{Rt}=\mathrm{Fpb}$ (Haggerty and Lindsley 1969) are also shown. Abbreviations are: $C S$, coesite; $E n$, enstatite; $F a$, fayalite; $F p b$, ferropseudobrookite; $F s$, ferrosilite; $G k$, geikielite; $I l m$, ilmenite; $K a r$, karrooite; $R t$, rutile; $Q z$, quartz mediate hypersthene in some granulite facies rocks (e.g., Moore 1968; Griffin et al. 1971; Anovitz 1987; Anovitz and Essene 1990). Therefore, we set out to calibrate the Sirf equilibria over the compositional range $\mathrm{Fs}_{40} \mathrm{En}_{60}-\mathrm{Fs}_{70} \mathrm{En}_{30}$.

\section{Experimental methods}

\section{Starting materials}

A combination of natural quartz from Brazil and synthetic orthopyroxene $_{\mathrm{ss}}$, ilmenite $_{\mathrm{ss}}$ and rutile were used as reactants in the experiments. The quartz and rutile were prepared by Bohlen et al. (1983b) and are stoichiometric. Different ilmenites were synthesized in evacuated silica tubes at $900^{\circ} \mathrm{C}$ by reacting appropriate molar quantities of $\mathrm{Fe}$ (iron metal), $\mathrm{Fe}_{2} \mathrm{O}_{3}$ (hematite), $\mathrm{TiO}_{2}$ (anatase) and $\mathrm{MgO}$ (periclase). Multiple grinding and heating cycles were necessary to obtain homogeneous ilmenite; total synthesis times ranged from 8 to 15 days. Between each cycle the materials were ground together under acetone for approximately one hour and were then packed into $5 \mathrm{~mm}$ outer diameter (o.d.) Au capsules, which were crimped at the bottom and left open at the top. It was necessary to dry the powder-packed Au capsules overnight in a vacuum oven at $100^{\circ} \mathrm{C}$ between each cycle in order to prevent loss of the sample upon evacuation in the silica tube. All starting materials were characterized using optical, X-ray diffraction (Xrd), scanning electron microscope (Sem) and electron microprobe analysis (Empa) techniques. The Empa indicates that the ilmenite is homogeneous and stoichiometric within analytical uncertainty of the microprobe, and that less than $2 \mathrm{~mol} \%$ hematite component is required to satisfy charge balance requirements (Table 1 ). A focused beam with an accelerating potential of $15 \mathrm{kV}$ and a sample current of $0.030 \mu \mathrm{A}$ were standard operating conditions. Counting times (at least $30 \mathrm{~s}$ ) were sufficient to maintain a precision of $\pm 0.5 \%$ for all major elements in standards and unknowns. Well-characterized synthetic rutile, hematite and spinel were used for titanium, iron, magnesium and aluminum. Analytical data were corrected using the procedures of Bence and Albee (1968).

Synthesis of orthopyroxene provided some difficulties. Initial attempts to sinter oxides at $1 \mathrm{~atm}$ in a DelTech furnace with a gas-mixing attachment at $1050^{\circ} \mathrm{C}$ following procedures of Turnock et al. (1973) yielded mixtures of olivine, clinohypersthene and tridymite. Despite repeated cycles of grinding and refiring it was difficult to eliminate the initially formed olivine. Therefore, orthopyroxene was synthesized at $1000^{\circ} \mathrm{C}$ and $15 \mathrm{kbar}$ in a piston-cylinder apparatus. Mixtures of appropriate molar quantities of iron metal, $\mathrm{MgO}$ (periclase) and $\mathrm{SiO}_{2}$ (natural quartz) were ground together under acetone for one hour, and approximately $250 \mathrm{mg}$ of powder were loaded into $5 \mathrm{~mm}$ o.d. Au capsules. Five weight percent excess quartz was added to suppress formation of olivine. Sufficient $\mathrm{H}_{2} \mathrm{O}$

Table 1. Representative electron microprobe analyses of ilmenite starting materials

\begin{tabular}{|c|c|c|c|c|c|c|}
\hline $\begin{array}{l}\text { Experiment no. } \\
\text { Analysis point }\end{array}$ & $\begin{array}{l}\operatorname{Ilm} \\
1\end{array}$ & $\begin{array}{l}\text { Geik }_{4} \\
8\end{array}$ & $\begin{array}{l}\mathrm{Geik}_{8} \\
1\end{array}$ & $\begin{array}{l}\text { Geik }_{12} \\
4\end{array}$ & $\begin{array}{l}\text { Geik }_{16} \\
10\end{array}$ & $\begin{array}{l}\text { Geik }_{20} \\
2\end{array}$ \\
\hline $\mathrm{TiO}_{2}$ & 52.62 & 52.33 & 52.31 & 52.94 & 53.35 & 54.21 \\
\hline $\mathrm{Al}_{2} \mathrm{O}_{3}$ & 0.12 & 0.11 & 0.09 & 0.06 & 0.05 & 0.10 \\
\hline $\mathrm{Fe}_{2} \mathrm{O}_{3}$ & 0.32 & 1.09 & 2.12 & 2.36 & 2.47 & 1.82 \\
\hline $\mathrm{FeO}$ & 47.22 & 44.85 & 42.92 & 41.19 & 39.59 & 38.24 \\
\hline $\mathrm{MgO}$ & 0.05 & 1.24 & 2.31 & 3.60 & 4.70 & 5.88 \\
\hline Total & 100.33 & 99.62 & 99.75 & 100.15 & 100.16 & 100.25 \\
\hline$X_{\mathrm{GK}}$ & 0.002 & 0.046 & 0.086 & 0.131 & 0.171 & 0.211 \\
\hline
\end{tabular}

$X_{\mathrm{Gk}}=\mathrm{Mg} /\left(\mathrm{Mg}+\mathrm{Fe}^{2+}+0.5 \mathrm{Fe}^{3+}\right)$. All analyses obtained with an Arl-Semq electron microprobe. Ilm, ilmenite; geik, geikielite 
Table 2. Representative electron microprobe analyses of orthopyroxene starting materials

\begin{tabular}{|c|c|c|c|c|c|c|c|c|c|}
\hline $\begin{array}{l}\text { Experiment no. } \\
\text { Analysis point }\end{array}$ & $\begin{array}{l}22 \mathrm{C} \\
3\end{array}$ & $\begin{array}{l}20 B \\
2 a\end{array}$ & $\begin{array}{l}31 \mathrm{C} \\
4\end{array}$ & $\begin{array}{l}34 \mathrm{Br} \\
8\end{array}$ & $\begin{array}{l}34 \mathrm{Bc} \\
15\end{array}$ & $\begin{array}{l}22 \mathrm{C}^{\mathrm{a}} \\
23\end{array}$ & $\begin{array}{l}20 B^{a} \\
2 b\end{array}$ & $\begin{array}{l}31 \mathrm{C}^{\mathrm{a}} \\
3\end{array}$ & $\begin{array}{l}34 \mathrm{Br}^{\mathrm{a}} \\
29\end{array}$ \\
\hline $\mathrm{SiO}_{2}$ & 53.19 & 51.42 & 50.96 & 49.59 & 50.11 & 53.34 & 51.90 & 50.47 & 48.91 \\
\hline $\mathrm{Al}_{2} \mathrm{O}_{3}$ & 0.14 & 0.12 & 0.09 & 0.15 & 0.18 & 0.03 & 0.03 & 0.07 & 0.03 \\
\hline $\mathrm{Cr}_{2} \mathrm{O}_{3}$ & 0.03 & 0.07 & 0.12 & 0.02 & 0.03 & - & - & - & - \\
\hline $\mathrm{Fe}_{2} \mathrm{O}_{3}$ & 0.25 & 0.72 & 0.00 & 0.00 & 0.97 & 0.00 & 0.00 & 0.00 & 0.49 \\
\hline $\mathrm{MnO}$ & 0.17 & 0.19 & 0.17 & 0.27 & 0.35 & 0.11 & 0.12 & 0.22 & 0.22 \\
\hline $\mathrm{CaO}$ & 0.03 & 0.01 & 0.02 & 0.02 & 0.02 & - & - & - & - \\
\hline $\mathrm{Na}_{2} \mathrm{O}$ & 0.00 & 0.00 & 0.00 & 0.00 & 0.00 & - & - & - & - \\
\hline Total & 100.16 & 100.12 & 100.27 & 100.52 & 100.21 & 99.68 & 100.35 & 99.42 & 99.71 \\
\hline$X_{\mathrm{Fs}}$ & 0.386 & 0.495 & 0.582 & 0.674 & 0.580 & 0.395 & 0.503 & 0.587 & 0.681 \\
\hline
\end{tabular}

$X_{\mathrm{Fs}}=\mathrm{Fe}^{2+} /\left(\mathrm{Fe}^{2+}+\mathrm{Mg}\right){ }^{\text {a }}$ Analyzed with a Cameca electron microprobe; other analyses obtained with an Arl-Semq electron microprobe

Table 3. Average compositions of synthetic starting materials

\begin{tabular}{lllll}
\hline \multicolumn{2}{l}{ Orthopyroxene, mol\% Fs } & & \multicolumn{2}{l}{$\mathrm{Ilm}, \mathrm{mol} \%$ Geik } \\
\cline { 1 - 1 } Ideal & Analyzed & & Ideal & Analyzed \\
\hline 40 & $39(1)$ & & $0.6(8)$ \\
50 & $51(1)$ & & $4.5(2)$ \\
60 & $59(1)$ & 8 & $8.9(6)^{\mathrm{a}}$ \\
70 & $68(1)$ rim & 12 & $13.0(8)$ \\
& $59(2)$ core & 16 & $16.9(4)$ \\
& & 20 & $21.1(12)$ \\
\hline
\end{tabular}

The stoichiometry of the oxide reactants, in terms of mole percent ferrosilite and geikielite, is indicated as "ideal" values. Average compositions of the actual synthesized products, based on electron microprobe results, are listed as analyzed values to the right. Estimated standard deviations are given in parentheses (2 ESD). Compositions of some cores for $\mathrm{Fs}_{70}$ are more magnesian than rims by an average of 9 mole $\%$

a Synthesized by A.M. Koziol

was added to oxidize the iron, plus $2 \mathrm{wt} \%$ excess $\mathrm{H}_{2} \mathrm{O}$ as a flux ( $\sim 20 \mu \mathrm{l}$ total) and the Au capsules were arc welded at both ends. A minimum of two heating cycles ( 3 days each) was necessary to produce yields of orthopyroxene + quartz. Optical, Xrd, Sem and Emp observations indicate that subhedral crystals of orthopyroxene up to $50 \mu \mathrm{m}$ in length are homogeneous and stoichiometric. The maximum variation in composition within individual orthopyroxene crystals is only $1-2 \mathrm{~mol} \%$ for $\mathrm{Fs}_{40-60}$, with cores being more magnesium rich. This is within analytical error of the electron microprobe but probably indicates a real difference as it was systematically observed. In $\mathrm{Fs}_{70}$, a few crystals have small, magnesium-rich cores with broad homogeneous rims that are more iron rich (Fig. 2 b). Zoning in some of the $\mathrm{Fs}_{70}$ starting material does not hinder determination of reaction direction because all experiments conducted with this initial composition were driven toward more magnesian values, such that the sense of zoning in the product was reversed from that of the starting material. No evidence of olivine, periclase or iron metal was found in the synthetic products. As expected, excess quartz is present as discrete crystals and as tiny inclusions in some of the orthopyroxene crystals. Representative electron microprobe analyses of orthopyroxene starting materials obtained with an Arl-Semq electron microprobe (Usgs) are given in Table 2. Operating conditions were the same as for ilmenite.
Clinopyroxene (Goldich et al. 1967), Johnstown hypersthene (Jarosewich et al. 1980), jadeite (Coleman 1961) and synthetic fayalite and $\mathrm{Mn}_{2} \mathrm{O}_{3}$ were used as standards for silicon, magnesium, aluminum, iron and manganese, respectively. Average compositions of orthopyroxene and ilmenite starting materials determined with the Arl-Semq microprobe are given in Table 3.

Analyses of starting materials were also obtained with a Cameca Camebax electron microprobe (Univ. of Michigan) to check for systematic errors in the chemical data (Table 2). A focused beam with an accelerating potential of $15 \mathrm{kV}$ and a sample current of $0.010 \mu \mathrm{A}$ were standard operating conditions. Precision was maintained at $\pm 0.5 \%$ for all elements in standards and unknowns. For pyroxene analyses, clinopyroxene from Delegate, New South Wales (Irving 1974), Marjahlati olivine (Yoder and Sahama 1957), Kakanui hornblende (Jarosewich et al. 1980), Broken Hill rhodonite (ANU, N. Ware, personal communication) and synthetic ferrosilite were used a standards for silicon, magnesium, aluminum, manganese and iron, respectively. For ilmenite, synthetic rutile, hematite, geikielite, spinel and Broken Hill rhodonite were used for analysis of titanium, iron, magnesium, aluminum and manganese. Analytical data were corrected using the Cameca PAP program. Some analyses of orthopyroxene starting materials obtained with the $\mathrm{Ca}$ meca electron microprobe appear to be slightly richer in iron, but within analytical uncertainties the results are in agreement with the Arl-Semq instrument. Compositions of ilmenite starting materials obtained with both microprobes are indistinguishable.

\section{Apparatus and experimental procedure}

Various mixtures of the Sirf assemblage involving solid solution between equilibria (1) and (2) were prepared by grinding together stoichiometric proportions for (1) and (2) for several minutes under acetone. For each experiment, $12-15 \mathrm{mg}$ of the mixture were characterized by $\mathrm{Xrd}$ and loaded into $1.6 \mathrm{~mm}$ o.d. $\mathrm{Ag}_{80} \mathrm{Pd}_{20}$ capsules. For experiments at $800^{\circ} \mathrm{C}, 1 \mathrm{mg}$ of $\mathrm{H}_{2} \mathrm{O}$ was added to the reactants in the inner capsule to enhance reaction rates; $0.5 \mathrm{mg}$ of $\mathrm{H}_{2} \mathrm{O}$ was added to the inner capsule for experiments conducted at $900^{\circ} \mathrm{C}$. At $1000^{\circ} \mathrm{C}$, starting materials were loaded dry but no special measures were taken to eliminate moisture and at $1100^{\circ} \mathrm{C}$ inner capsules were heated for 15 minutes at $100^{\circ} \mathrm{C}$ before sealing to eliminate all moisture. The fugacity of oxygen was buffered near ironwïstite (IW) to suppress the formation of ferric iron by loading the $1.6 \mathrm{~mm}$ o.d. capsules into $3 \mathrm{~mm}$ o.d. Pt capsules together with $100-150 \mathrm{mg}$ of iron metal powder and sufficient $\mathrm{H}_{2} \mathrm{O}$ to react about $75 \%$ of the iron metal to wüstite (Eugster 1957). Capsule openings 

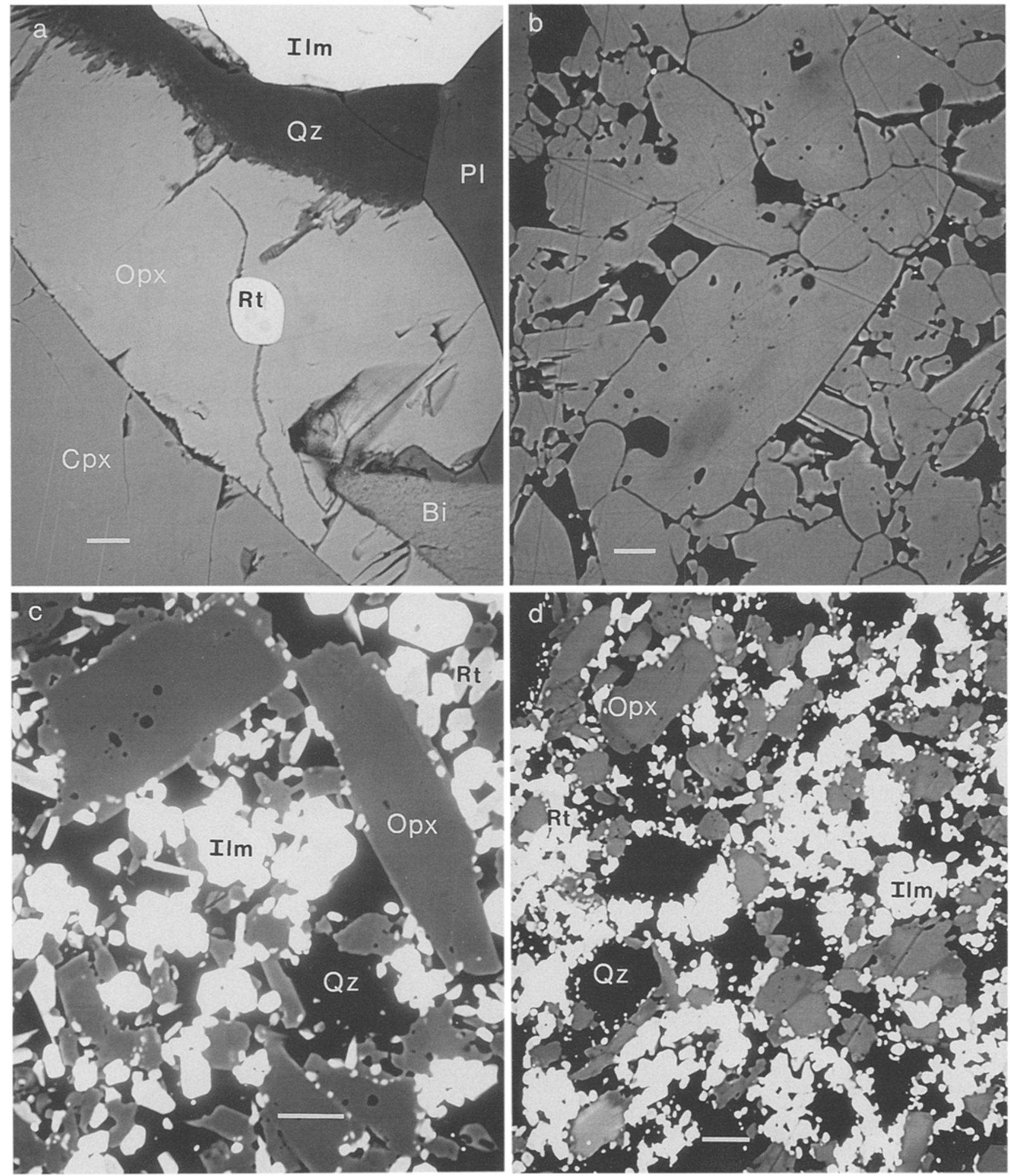

Fig. 2a-d. Back-scattered electron images of the Sirf assemblage in a natural sample and in experimental samples that show zoning in orthopyroxene. Scale bars are $10 \mu \mathrm{m}$ and abbreviations are: $B i$, biotite; $C p x$, clinopyroxene; $I / m$, ilmenite; $O p x$, orthopyroxene; $P l$, plagioclase; $Q z$, quartz and $R t$, rutile. a Sirf assemblage in sample

Ros-83C-16 from the Rosseau domain, Grenville Province; b zoning in ' $\mathrm{Fs}_{70}$ ' starting material from $\sim \mathrm{FS}_{59}$ (core) to $\mathrm{Fs}_{68}$ (rim); c, d polished samples from experiments $49 \mathrm{~A}$ and $49 \mathrm{~B}$, respectively, at $800^{\circ} \mathrm{C}$ and $14 \mathrm{kbar}$ 

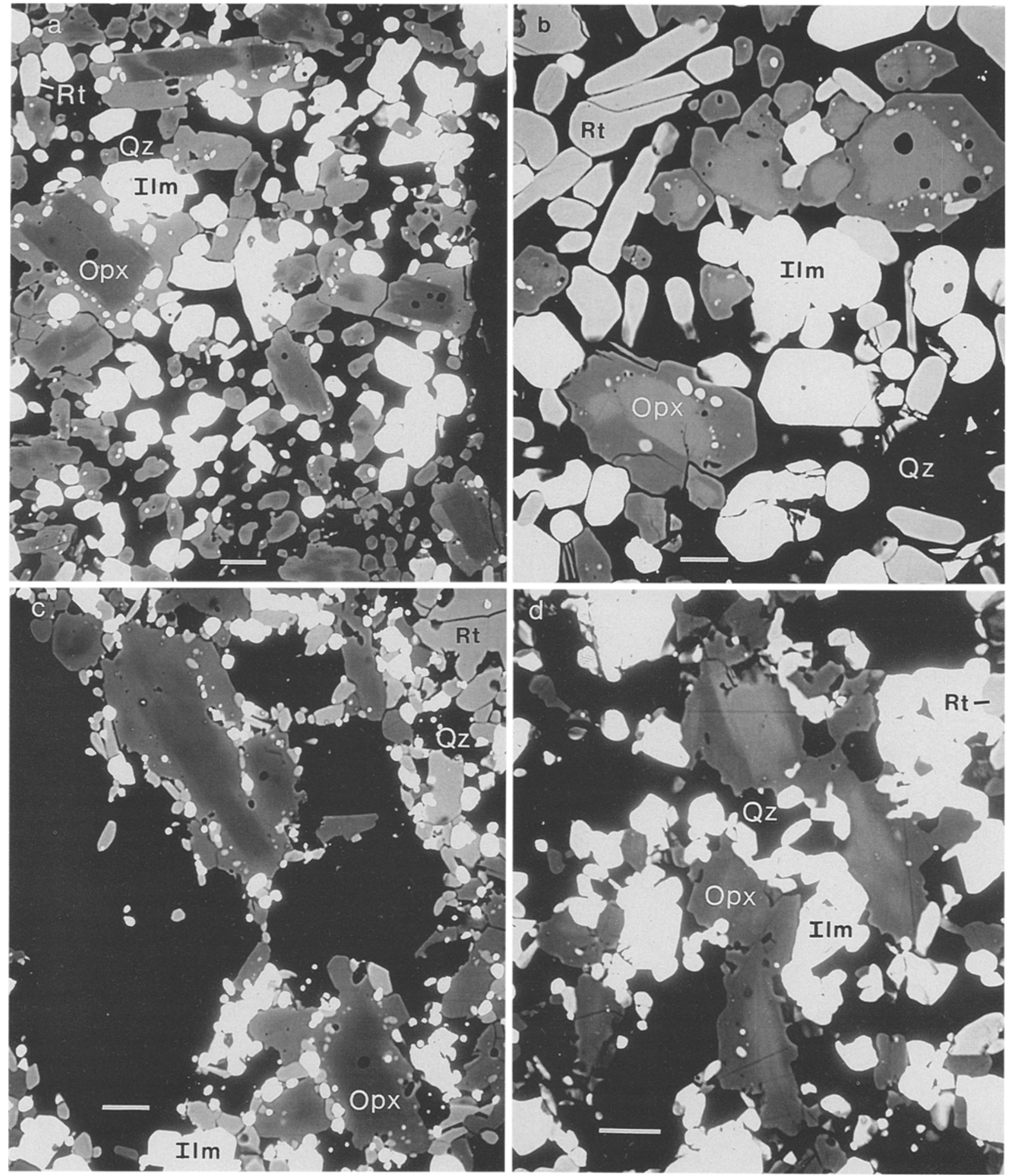

Fig. 3a-d. Back-scattered electron images of experimental samples that show zoning in orthopyroxene. Scale bars are $10 \mu \mathrm{m}$ and abbreviations as in Fig. 2. a, b Polished samples from experiments

were carefully cleaned and sealed by arc welding. All capsules were surrounded by wet tissue during welding and were weighed after weding to ensure that no loss of $\mathrm{H}_{2} \mathrm{O}$ occurred.

All experiments were conducted in an end-loaded, piston-cylinder apparatus with $2.54 \mathrm{~cm}$-diameter pistons. The Sirf equilibria

$53 \mathrm{~A}$ and $53 \mathrm{~B}$, respectively, at $900^{\circ} \mathrm{C}$ and $19.5 \mathrm{kbar}$; $\mathbf{c}$, d polished samples from experiments $48 \mathrm{~A}$ and $38 \mathrm{~B}$, respectively, at $1000^{\circ} \mathrm{C} /$ $23.4 \mathrm{kbar}$ and $1000^{\circ} \mathrm{C} / 13.4 \mathrm{kbar}$

were reversed at identical pressure-temperature conditions for most experiments by placing two separate capsules side-by-side in the center of the furnace assemblies. In most experiments, one capsule ('A') contained the Sirf assemblage with relatively magnesium-rich orthopyroxene and iron-rich ilmenite, and the other capsule (' $\mathrm{B}$ ') 
contained iron-rich orthopyroxene and magnesium-rich ilmenite as starting materiais (Table 4). In three experiments (nos. 35, 36, 37), capsule A contained magnesium-rich ilmenite and magnesiumrich orthopyroxene, and capsule $B$ contained iron-rich ilmenite with an iron-rich orthopyroxene. Three other experiments also contained similar starting materials (nos. 21, 26, 30). In either case, the continuous exchange reaction (3) was reversed in most experiments. Reversals were obtained for the discontinuous reaction involving solid solution between equilibria (1) and (2) over most of the $P-T$ range investigated (Table 4 ). Furnace assemblies were composed of graphite heating elements and $\mathrm{NaCl}$ pressure media (Bohlen et al. 1983b; Bohlen 1984). Pressures were calibrated over the $P-T$ range of interest using the melting point of $\mathrm{LiCl}$ (Clark 1959; Bohlen and Boettcher 1982). In each experiment, pressure was advanced to around $80 \%$ of the desired value. Temperature was increased to the final value, during which the pressure rose as a result of thermal expansion of the $\mathrm{NaCl}$. Pressure was then increased to the final value and pressures were maintained to \pm 100 bars during each experiment with digital Heise 710 A gauges. Temperatures were held to $\pm 1^{\circ} \mathrm{C}$ with $\mathrm{Pt}-\mathrm{Pt}_{90} \mathrm{Rh}_{10}$ thermocouples resting on the capsules and were not corrected for the effect of pressure on emf. The measurement of pressure is estimated to have $\pm 0.1 \mathrm{kbar}$ precision and $\pm 0.5 \mathrm{kbar}$ accuracy; temperature measurements are precise to $\pm 1^{\circ} \mathrm{C}$ and accurate to $\pm 5^{\circ} \mathrm{C}$. Boron nitride powder, a good thermal conductor, was packed around the capsules to minimize thermal gradients, which are less than $5^{\circ} \mathrm{C}$ across capsules (Bohlen 1984)

\section{Products}

The products of all experiments were analyzed optically and with Xrd, Sem and Emp techniques. Most chemical analyses were obtained at the Usgs, Menlo Park, using an automated Arl-Semq electron microprobe with wavelength dispersive crystal spectrometers (Tables 5 and 6). Operating conditions were the same as for the starting materials.

To check for systematic errors, some analyses of orthopyroxene were obtained at the University of Michigan with an automated Cameca electron microprobe. Representative analyses of orthopyroxene products obtained with both electron microprobes are given in Table 6. Minor amounts (typically $0.1-0.2$ oxide wt $\%$ ) of $\mathrm{Al}$ and $\mathrm{Mn}$ were detected with both instruments in most starting materials and products, although smaller amounts were detected with the Cameca microprobe. The detection limit of both electron microprobes for the operating conditions used is $\sim 0.04-0.06$ oxide $\mathrm{wt} \%$ (99\% confidence level, Eq. 8.45 of Goldstein et al. 1981), although it varies slightly depending on the estimated standard deviations and the number of analyses for each phase. The presence of minor amounts of $\mathrm{Al}$ and $\mathrm{Mn}$ in the pyroxene and ilmenite must be the result of slight contamination of starting materials because these elements are too large to diffuse through the platinum and silver paladium capsules. Greater uncertainties in the detection of $\mathrm{Al}$ and $\mathrm{Mn}$ with the Arl-Semq instrument may in part be related to difficulties in accurate measurement of background concentrations with fixed spectrometers.

\section{Experimental results}

For most experiments, reaction direction was not obvious from optical examination of the products. In many cases, growth of either the high (orthopyroxene + rutile) or low (ilmenite + quartz) pressure side of the equilibria could be inferred from changes in relative peak intensities of X-rays (Table 4). Back-scattered electron (Bse) images of products were also used to infer growth of the high pressure side. Orthopyroxene crystals typically show sharp boundaries between overgrowths of newly
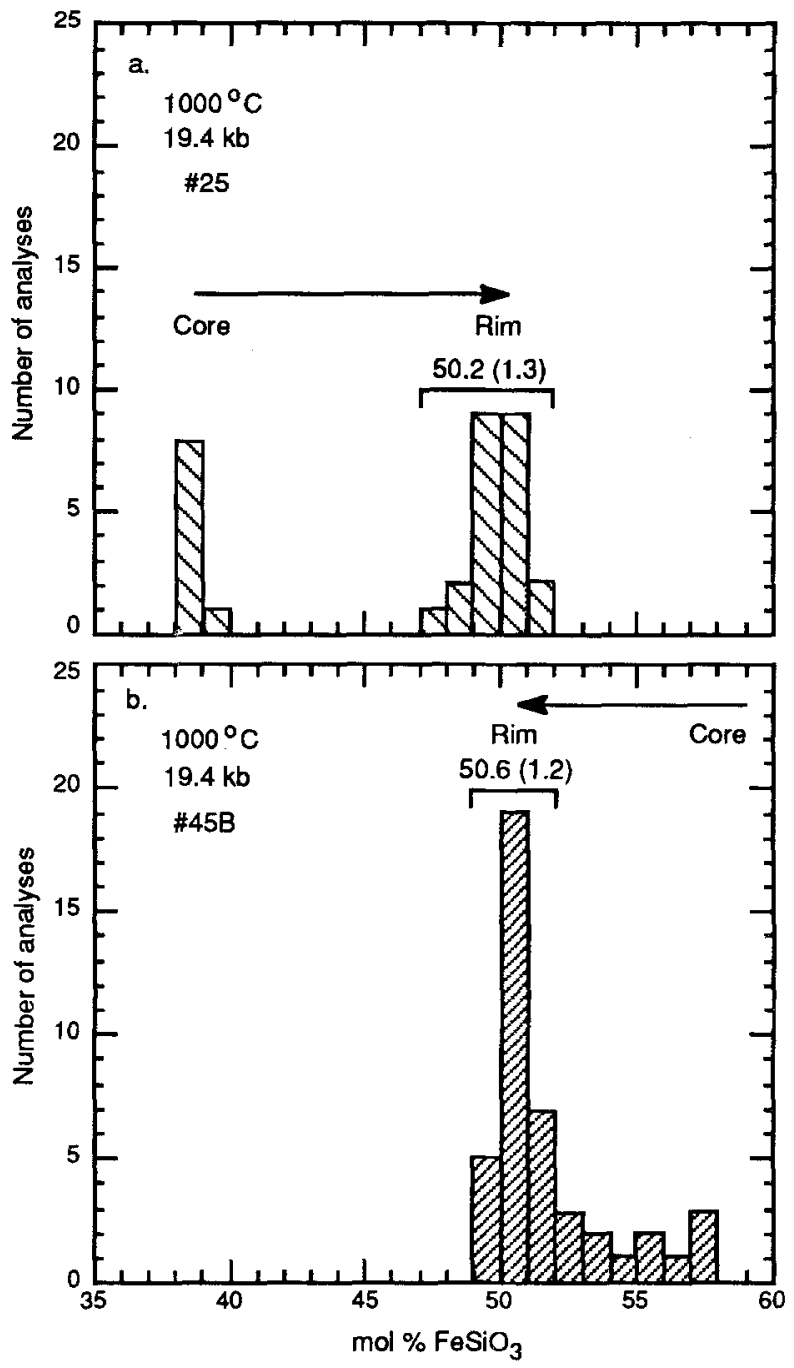

Fig. 4a, b. Histograms of core and rim compositions of orthopyroxene from experiments at $1000^{\circ} \mathrm{C}$ and 19.4 kbar. a Experiment 25 contained an orthopyroxene starting material of $\mathrm{Fs}_{39}$; rims of products changed to $\sim \mathrm{Fs}_{50}$; $\mathrm{b}$ experiment $45 \mathrm{~B}$ contained a more iron-rich orthopyroxene starting material of $\mathrm{Fs}_{59}$; rims of products changed to $\sim \mathrm{Fs}_{50}$. Rim values are averages with $2 \mathrm{ESD}$ (estimated standard deviation) in parentheses

formed, inclusion-rich orthopyroxene and original seed crystals for experiments in which the high pressure side grew (Figs. $2 \mathrm{c}, 3 \mathrm{a}-\mathrm{c}, 4 \mathrm{a}$ ). The growth of new orthopyroxene supports the assumption that zoning in some of the $\mathrm{Fs}_{70}$ starting material did not affect the attainment of equilibrium in the Sirf experiments (cf., Fig. 3 b). For experiments in which the low pressure side grew, edges of some orthopyroxene crystals are embayed and compositional zoning in orthopyroxene tends to be more diffuse (e.g., Fig. 4b). This texture was not considered to be conclusive, however, in determining growth of the low pressure side because zoning in orthopyroxene could be produced simply by the diffusion of iron and magnesium between orthopyroxene and ilmenite. Ilmenite products are not zoned within analytical uncertainty of the electron microprobe. Electron microprobe analysis of ilmenite and orthopyroxene products confirmed that equilibrium (3) was reversed in most experiments (Ta- 

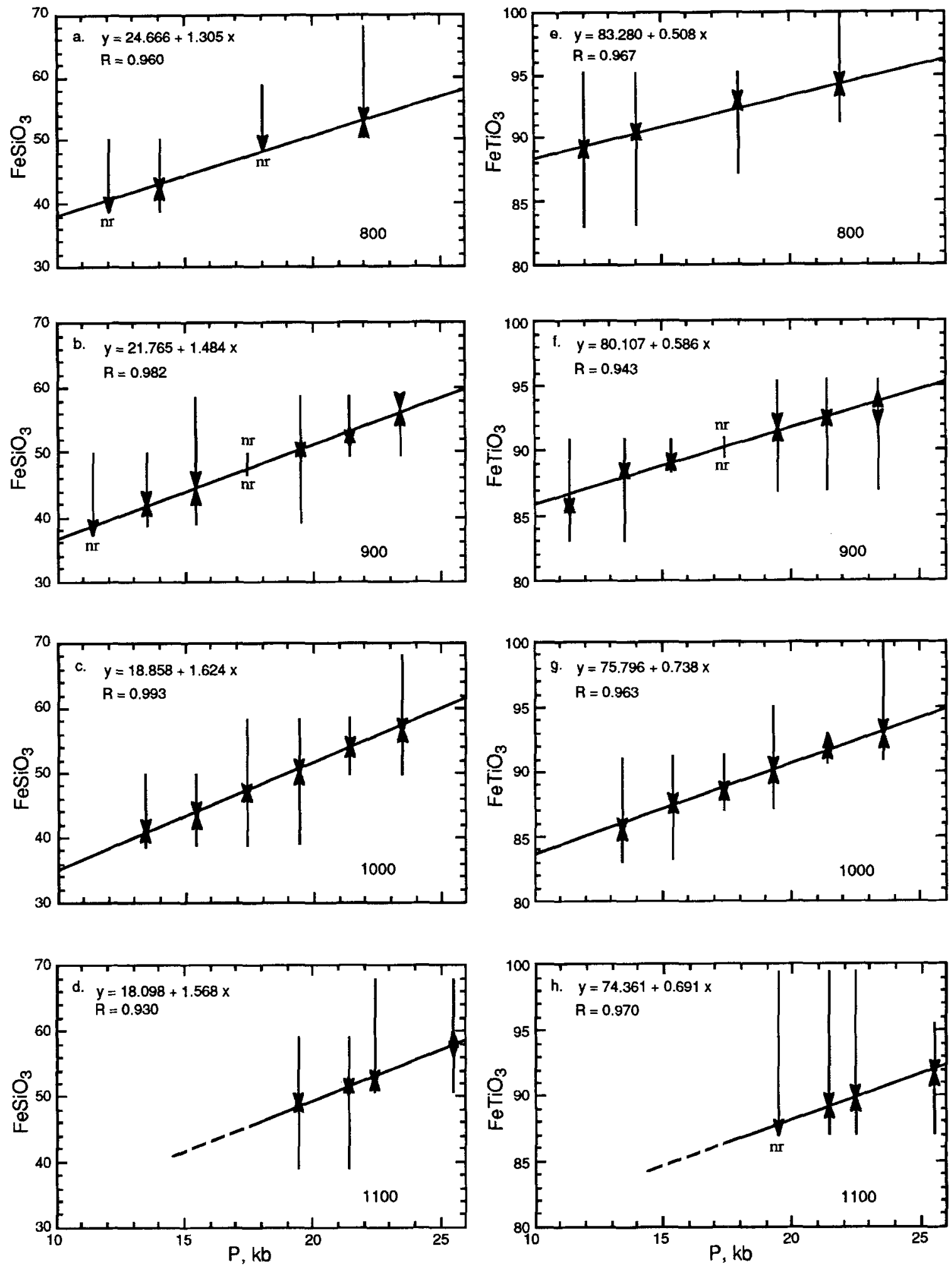

Fig. 5a-h. Composition versus pressure diagrams of experimental reversals at $800-1100^{\circ} \mathrm{C}$. Arrows show reaction direction. Amount of reaction is indicated by line length and extreme compositions are represented by arrow tips. Lengths of arrowheads correspond in pressure is $\pm 0.5 \mathrm{kbar}$. Curves are least-squares fits to half-reversals. a-d Mole percent ferrosilite versus pressure; e-h mole percent ilmenite versus pressure. A change in composition of $<2 \mathrm{~mol} \%$ is taken as no reaction, $n r$ to $\sim 2 \mathrm{~mol} \%$ and represent error in composition. Estimated error 
Table 4. Experimental conditions and results

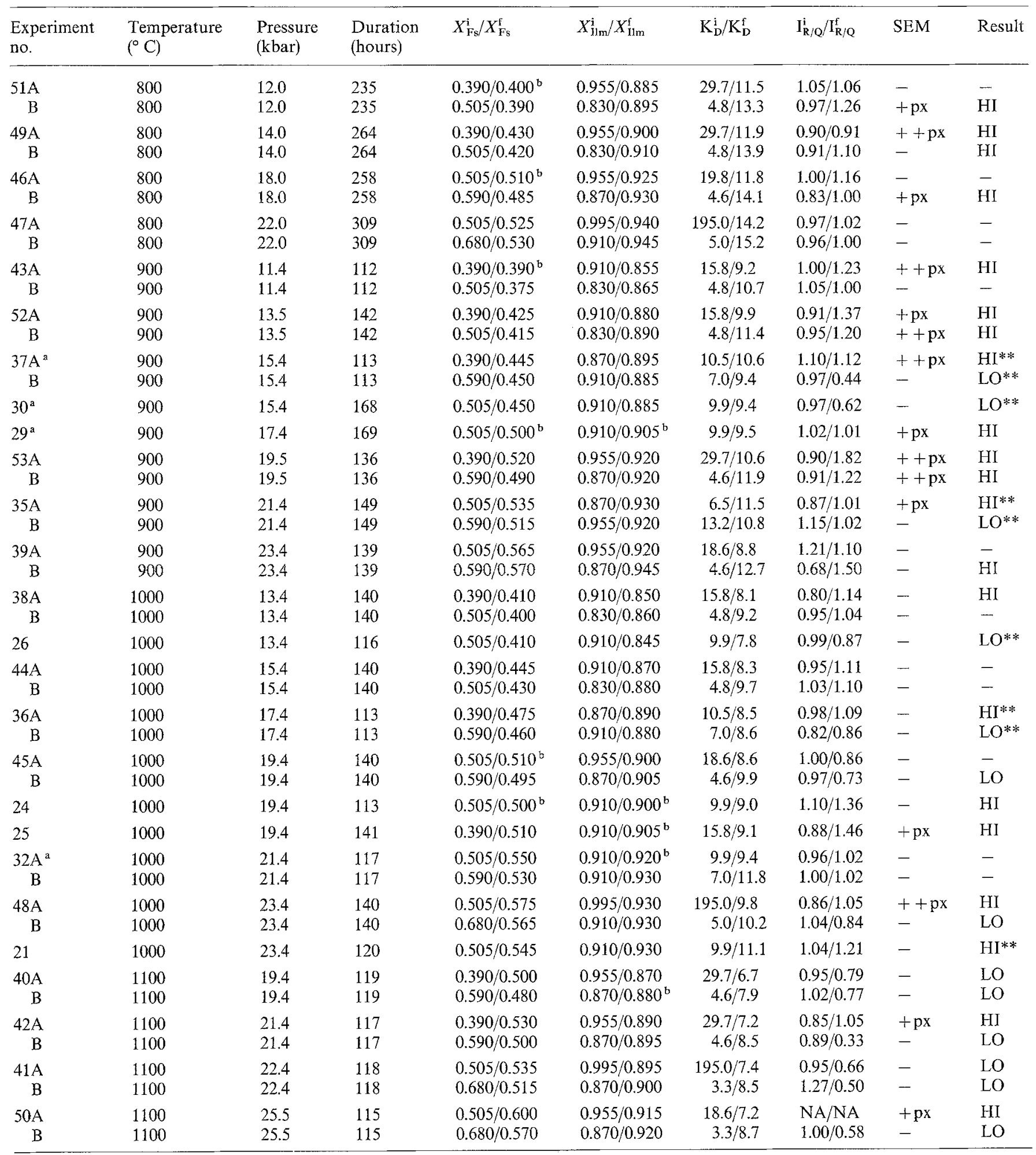

A, initial orthopyroxene was relatively magnesium-rich; $B$, initial orthopyroxene was iron-rich; i,f, initial and final, maximum differences in compositions of phases, relative to initial values, are given; $\mathrm{I}_{\mathrm{R} / \mathrm{Q}}^{\mathrm{iorf}}=\mathrm{I}(110)_{\mathrm{R} /} / \mathrm{I}(101)_{\mathrm{Q}_{\mathrm{Z}}}$ for initial starting materials and final products. Slide of X-ray mount for No. 50A was dropped and contaminated, NA, not analyzed; SEM, scanning electron microscopy; + px, moderate overgrowth of orthopyroxene with inclusions; $++\mathrm{px}$, strong overgrowth of orthopyroxene with inclusions; - , no overgrowth of orthopyroxene; HI, growth of high pressure side (rt
+ opx $\left._{\mathrm{ss}}\right)$; LO, growth of low pressure side $\left(\mathrm{ilm}_{\mathrm{ss}}+\mathrm{qz}\right)$. ** Growth of the high or low pressure side must have occurred for compositions of orthopyroxene (opx) and ilm to change in the same direction. Rt, rutile; qz, quartz

${ }^{a} \mathrm{~K}_{D}$ was not reversed at these $P-T$ conditions; $K_{D}$ $=(\mathrm{Mg} / \mathrm{Fe})^{\mathrm{opx}} /(\mathrm{Mg} / \mathrm{Fe})^{\mathrm{i} / \mathrm{m}}$

${ }^{b}$ Composition of experimental product changed by $<2$ mol\% (no reaction) 
Table 5. Representative electron microprobe analyses of ilmenite products

\begin{tabular}{|c|c|c|c|c|c|c|c|c|}
\hline $\begin{array}{l}T,{ }^{\circ} \mathrm{C} \\
\text { Experiment no. } \\
\text { Analysis point }\end{array}$ & $\begin{array}{l}800 \\
46 \mathrm{~A} \\
14\end{array}$ & $\begin{array}{l}800 \\
51 \mathrm{~B} \\
2\end{array}$ & $\begin{array}{l}900 \\
52 \mathrm{~B} \\
9\end{array}$ & $\begin{array}{l}900 \\
53 \mathrm{~A} \\
4\end{array}$ & $\begin{array}{l}1000 \\
38 \mathrm{~B} \\
1\end{array}$ & $\begin{array}{l}1000 \\
45 B \\
8\end{array}$ & $\begin{array}{l}1100 \\
42 B \\
7\end{array}$ & $\begin{array}{l}1100 \\
50 \mathrm{~A} \\
1\end{array}$ \\
\hline Total & 99.67 & 100.62 & 100.07 & 99.95 & 100.85 & 100.30 & 99.21 & 100.24 \\
\hline$X_{\mathrm{Ilm}}$ & 0.928 & 0.889 & 0.883 & 0.920 & 0.853 & 0.897 & 0.885 & 0.917 \\
\hline
\end{tabular}

$X_{\mathrm{Ilm}}=\mathrm{Fe}^{2+} /\left(\mathrm{Fe}^{2+}+\mathrm{Mg}+0.5 \mathrm{Fe}^{3+}\right)$. All analyses obtained with an Arl-Semq electron microprobe

Table 6. Representative electron microprobe analyses of orthopyroxene products

\begin{tabular}{|c|c|c|c|c|c|c|c|c|c|c|c|}
\hline $\begin{array}{l}T,{ }^{\circ} \mathrm{C} \\
\text { Experiment no. } \\
\text { Analysis point }\end{array}$ & $\begin{array}{l}800 \\
46 \mathrm{~A} \\
22\end{array}$ & $\begin{array}{l}800 \\
51 \mathrm{~B} \\
4\end{array}$ & $\begin{array}{l}900 \\
52 \mathrm{~B} \\
1\end{array}$ & $\begin{array}{l}900 \\
53 \mathrm{~A} \\
7\end{array}$ & $\begin{array}{l}1000 \\
38 \mathrm{~B} \\
5\end{array}$ & $\begin{array}{l}1000 \\
25^{a} \\
55\end{array}$ & $\begin{array}{l}1000 \\
25 \\
15\end{array}$ & $\begin{array}{l}1000 \\
45 B^{\mathrm{a}} \\
25\end{array}$ & $\begin{array}{l}1000 \\
45 B \\
7\end{array}$ & $\begin{array}{l}1100 \\
42 B \\
6\end{array}$ & $\begin{array}{l}1100 \\
50 \mathrm{~A} \\
7\end{array}$ \\
\hline $\mathrm{TiO}_{2}$ & 0.86 & 1.22 & 0.94 & 1.12 & 0.98 & 1.19 & 1.31 & 0.99 & 1.19 & 1.60 & 1.48 \\
\hline $\mathrm{Al}_{2} \mathrm{O}_{3}$ & 0.23 & 0.19 & 0.21 & 0.24 & 0.18 & 0.07 & 0.10 & 0.09 & 0.17 & 0.22 & 0.25 \\
\hline $\mathrm{Cr}_{2} \mathrm{O}_{3}$ & 0.03 & 0.02 & 0.01 & 0.02 & 0.01 & - & 0.00 & - & 0.00 & 0.01 & 0.01 \\
\hline $\mathrm{MgO}$ & 16.80 & 21.18 & 20.14 & 16.00 & 20.59 & 17.11 & 16.93 & 16.80 & 16.86 & 16.87 & 13.64 \\
\hline $\mathrm{MnO}$ & 0.17 & 0.11 & 0.11 & 0.12 & 0.13 & 0.11 & 0.13 & 0.13 & 0.12 & 0.18 & 0.15 \\
\hline $\mathrm{CaO}$ & 0.01 & 0.07 & 0.12 & 0.19 & 0.13 & - & 0.05 & - & 0.09 & 0.14 & 0.03 \\
\hline $\mathrm{Na}_{2} \mathrm{O}$ & 0.00 & 0.00 & 0.00 & 0.00 & 0.01 & - & 0.01 & - & 0.01 & 0.05 & 0.01 \\
\hline Total & 100.54 & 100.24 & 99.85 & 99.66 & 100.00 & 100.91 & 99.95 & 99.65 & 99.92 & 100.71 & 100.25 \\
\hline
\end{tabular}

$X_{\mathrm{Fs}}=\mathrm{Fe}^{2+} /\left(\mathrm{Fe}^{2+}+\mathrm{Mg}\right)$

a Analyzed with a Cameca electron microprobe; other analyses obtained with an Arl-Semq microprobe

ble 4). Reversals of orthopyroxene and ilmenite compositions at $800-1100^{\circ} \mathrm{C}$ are plotted in Fig. $5 \mathrm{a}-\mathrm{h}$ as a function of pressure. In some experiments orthopyroxene compositions changed by as much as $15 \mathrm{~mol} \%$. An apparent change in composition of $<2 \mathrm{~mol} \%$ in orthopyroxene or ilmenite was taken as indicative of no reaction. The results of all experiments are given in Table 4 . The reversals are very well bracketed, with final ilmenite compositions converging to within one mol\% (excluding no. 39) and most pyroxene compositions to within $2 \mathrm{~mol} \%$.

Scanning electron microscopy was also useful for identifying experimental products and evaluating textural equilibrium. No unusual mineral phases were produced in any of the experiments except no. 54, conducted at the highest temperature and lowest pressure $\left(1100^{\circ} \mathrm{C}\right.$, $17 \mathrm{kbar}$ ), in which the assemblage orthopyroxene, ilmenite, olivine and quartz was produced. Orthopyroxene and ilmenite were the dominant phases in the charge with minor amounts of quartz rimmed by orthopyroxene. Olivine was locally produced in quartz deficient regions at the rim of the charge, and rutile was not observed.
Results from experiment no. 54 were not used in any thermodynamic calculations.

\section{Comparison of $K_{D}$ with previous studies}

Distribution data $\left.\left(K_{D}=(X \mathrm{Mg} / X \mathrm{Fe})^{\mathrm{opx}} / X \mathrm{Mg} / X \mathrm{Fe}\right)^{\mathrm{Ilm}}\right)$ determined by Bishop (1980) on the partitioning of iron and magnesium between orthopyroxene and ilmenite at $800-1100^{\circ} \mathrm{C}$ are in agreement with most of our results, although his reversals are not as tightly bracketed. Bishop's data at $1000^{\circ} \mathrm{C}$ are most discordant with ours, and suggest a larger $K_{D}(\sim 13.7$ compared to our 9.0$)$. We have also compared our results with $K_{D}$ data predicted by the Quilf program of Andersen et al. (1992). The Quilf program is based on experimental determination of the Quilf equilibrium (Quartz + Ülvospinel= Ilmenite + Fayalite; Frost et al. 1988), calibrations of various oxygen buffers and the calibration of the $\mathrm{Fe}-\mathrm{Ti}$ oxide geothermometer of Andersen and Lindsley (1988). Distribution values predicted from their model are in agreement with our results at $800^{\circ} \mathrm{C}$, but between 900 
$1100^{\circ} \mathrm{C}$ Quilf predicts values of $K_{D}$ that are larger by an average of 3 units $\left(13-11\right.$ versus $10-8$ at $900-1100^{\circ} \mathrm{C}$, respectively). An increase in the $X_{\mathrm{MgSiO}_{3}}^{\mathrm{Opx}}$ of $\sim 0.040 .06$ or an increase in the $X_{\mathrm{FeTiO}_{3}}^{\mathrm{Im}} \sim 0.01-0.03$ is necessary to bring our results into agreement with the Quilf model. The presence of ferric iron in ilmenite cannot explain the discrepancy in the two models because solid solution of hematite in ilmenite will decrease the $X_{\mathrm{FeTiO}_{3}}^{\mathrm{Ilm}}$.

\section{Equilibrium order-disorder in orthopyroxene}

Experimental results of Besancon (1981) and Anovitz et al. (1988) indicate that orthopyroxene within the compositional range $\mathrm{FS}_{39-81}$ will reach an equilibrium state of order-disorder on the octahedral M1 and M2 sites within about 5 minutes at $800^{\circ} \mathrm{C}$. At $900^{\circ} \mathrm{C}$, ordering of iron and magnesium in orthopyroxene begins within seconds (Besancon 1981; Anovitz et al. 1988). The orthopyroxene studied by Virgo and Hafner (1969) at $1000^{\circ} \mathrm{C}$ probably did order to lower temperatures upon quenching (Ganguly 1982). Quench rates with the piston cylinder are fairly rapid, with temperatures decreasing by about $300^{\circ} \mathrm{C}$ within 5 seconds. Thus, orthopyroxene from our experiments at $800-900^{\circ} \mathrm{C}$ should record an equilibrium state of order, and orthopyroxene from experiments at $1000-1100^{\circ} \mathrm{C}$ ordered to lower temperatures $\left(\sim 900^{\circ} \mathrm{C}\right)$ upon quenching. However, ordering during quenching will not affect the results of this study because the bulk composition of orthopyroxene is unaffected during such rapid quenching. All available data on order-disorder in orthopyroxene indicate that orthopyroxene rapidly attained an equilibrium degree of disorder in our experiments.

\section{Thermodynamic properties of orthopyroxene solid solutions}

\section{Symmetric binary solution model}

Activity-composition $(a / X)$ relations in orthopyroxene can be estimated from our experiments in the Sirf system if accurate mixing relations for ilmenite-geikielite solid solutions and volume data of the solids are available for the pressures and temperatures of interest. Ferrosilite was chosen as a standard state for orthopyroxene, at $P$ and $T$ defined either by the experiments or the locus of equilibrium (1). Thermodynamic data for the iron endmember (1) were used in all calculations. Activity coefficients $(\gamma)$ of orthopyroxene can be fit to a binary, symmetric solution model using Margules-type $W_{G}$ parameters (Thompson 1967). The pressure dependence of $W_{G}^{\mathrm{Opx}}$ (or of $\gamma$ ) can be estimated from volume data for orthopyroxene of intermediate composition. Figure six shows available volume data compiled for synthetic iron-magnesium orthopyroxenes. The volume of mixing for orthopyroxene along the enstatite-ferrosilite join is linear at room temperature for quenched samples, and thus $W_{G}^{\mathrm{opx}}$ is independent of pressure assuming that the effects of

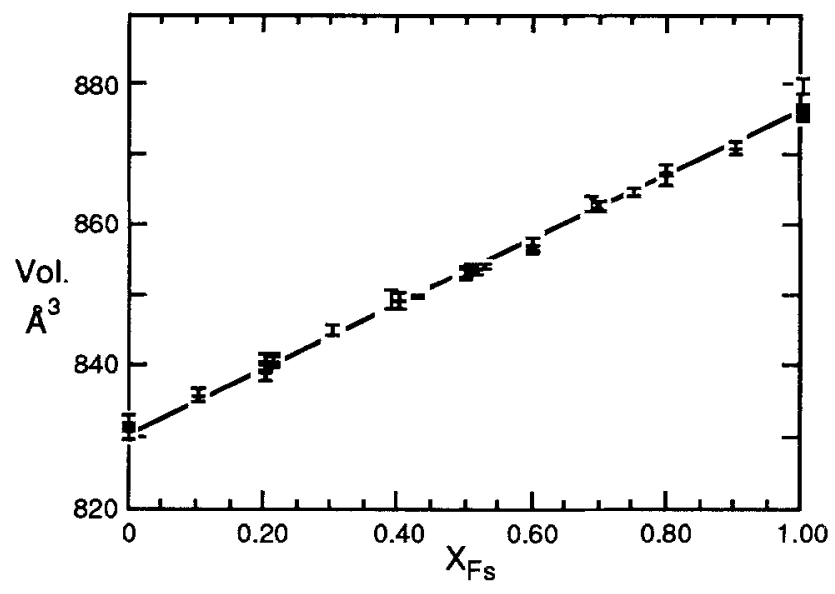

Fig. 6. Volumes of synthetic orthopyroxene versus composition for the system $\mathrm{MgSiO}_{3}-\mathrm{FeSiO}_{3}$. Data from this study are shown for $\mathrm{Fs}_{39}$ and $\mathrm{Fs}_{68}$. Enstatite data are from Stephenson et al. (1966), Matsui et al. (1968), Morimoto and Koto (1969), Turnock et al. (1973), *Hawthorne and Ito (1977) and Chatillon-Colinet et al. (1983). Ferrosilite data are from Akimoto et al. (1964), Matsui et al. (1968), Smith et al. (1969), Turnock et al. (1973), *Sueno et al. (1976), Chatillon-Colinet et al. (1983) and *Domeneghetti and Steffen (1992). Intermediate orthopyroxene data are from Matsui et al. (1968), Turnock et al. (1973), Chatillon-Colinet et al. (1983) and *Domeneghetti and Steffen (1992). Errors are 2 ESD as given by the authors. Curve is a linear least-squares regression to single crystal data (*): Vol. $=831.2+44.3 X_{\mathrm{Fs}}$

thermal expansion and compressibility do not produce non-linear relations at high pressure and temperature. Single-crystal X-ray refinements of synthetic orthopyroxene $\left(\mathrm{Fs}_{20}, \mathrm{Fs}_{50}\right.$ and $\left.\mathrm{Fs}_{100}\right)$ synthesized at $900^{\circ} \mathrm{C}$ and annealed at 650,850 and $1040^{\circ} \mathrm{C}$ indicate that volume is linear as a function of composition (Domeneghetti and Steffen 1992, Fig. 6). Orthopyroxene annealed at 650 and $850^{\circ} \mathrm{C}$ should preserve an equilibrium state of disorder, while samples annealed at $1040^{\circ} \mathrm{C}$ may have ordered to lower temperature during quenching (Besancon 1981; Anovitz et al. 1988). Domeneghetti and Steffen's (1992) orthopyroxene synthesized at $900^{\circ} \mathrm{C}$ should also preserve an equilibrium state of disorder. Thus, order-disorder apparently has no effect on the volume of quenched solid solutions of iron-magnesium orthopyroxene that equilibrated between about 650 and $900^{\circ} \mathrm{C}$.

Equilibrium (1) will be difficult to locate experimentally because it is metastable. In addition, it is located at pressures that are too high for the piston-cylinder apparatus ( $>45 \mathrm{kbar}$ ) for temperatures at which reaction rates are reasonably fast $\left(\geq 800^{\circ} \mathrm{C}\right.$, Fig. 1). To determine $a / X$ relations of orthopyroxene without relying on the locus of the iron end-member (1), experiments at two different pressures are necessary, at the same temperature, to obtain a solution of $W_{G}^{\text {opx }}$ (for $W_{G}^{\text {Opx }}$ independent of pressure) from

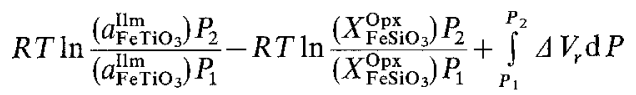

$$
\begin{aligned}
& =\left(X_{\mathrm{En} P_{2}}^{2}-X_{\mathrm{En} P_{1}}^{2}\right) W_{G}^{\mathrm{Opx}}
\end{aligned}
$$

where $\left(X_{\mathrm{En}}\right)^{2} W_{G}^{\mathrm{Opx}}=R T \ln \gamma_{\mathrm{FeSSiO}}^{\mathrm{Oppx}}$ (Thompson 1967). 
The temperature dependence of $W_{G}^{\mathrm{Opx}}$ can be estimated from multiple least-squares regression of Eq. (4) for the Sirf data as a function of temperature. A plot of $W_{G}^{\mathrm{Opx}}$ versus $T$ should produce a linear trend if there is no pressure dependence of $W_{G}^{\mathrm{Opx}} ; W_{H}^{\mathrm{Opx}}$ (excess enthalpy term) can then be obtained from the y-intercept and $W_{S}^{\text {opx }}$ (excess entropy term) from the slope of the fitted line. At $800,900,1000$ and $1100^{\circ} \mathrm{C}, n-1$ equations of the form of (4) were derived from $n$ experiments for which equilibrium could be demonstrated. Pressures and temperatures were controlled experimentally and compositions of experimental products were measured with an electron microprobe. Because midpoints of experimental reversals do not a priori reflect equilibrium conditions, mineral compositions used in the calculations were estimated from linear least-squares regression of individual half-brackets as a function of pressure (Fig. $5 \mathrm{a}-\mathrm{h}$ ); higher-order polynomial fits to the data are not justified given errors in the electron microprobe data. Activitycomposition relations of Andersen et al. (1991) and Ghiorso (1990) were used for ilmenite. Results from $\mathrm{Li}$ and Cao (1982) on the thermodynamics of mixing for ilmenite-geikielite solid solutions have been disregarded because their data for the reduction of pure ilmenite to rutile + metallic iron disagree with other experimental and thermodynamic data (Anovitz et al. 1985). The activity of $\mathrm{SiO}_{2}$ was set equal to unity, and the activity of $\mathrm{TiO}_{2}$ cancels because rutile compositions were constant $\left(X_{\mathrm{TiO}_{2}}^{\mathrm{Rut}}=0.98\right)$ over the $P-T$ range investigated. Volume data were obtained from the thermodynamic data base of Berman (1988).

Solution of Eq. (4) for $W_{G}^{\mathrm{Opx}}$ using data from this study on the equilibrium compositions of coexisting orthopyroxene and ilmenite at $800,900,1000$ and $1100^{\circ} \mathrm{C}$ produces a trend of increasing $W_{G}^{\text {opx }}$ with increasing temperature, requiring that non-ideality in $\mathrm{FeSiO}_{3}-\mathrm{MgSiO}_{3}$ orthopyroxene is greater at higher temperatures (Fig. 7). A recent analysis of available site occupancy data by Shi et al. (1992) suggests that non-ideality increases with increasing temperature for $\mathrm{FeSiO}_{3}-\mathrm{MgSiO}_{3}$ orthopy- roxene based on a one-site model. However, estimated errors are large for $W_{G}^{\text {Opx }}$ determined in this study and $W_{G}^{\text {Opx }}$ can be assumed to be independent of temperature. A $W_{G}^{\mathrm{Opx}}=W_{H}^{\mathrm{Opx}}$ of $3.6 \pm 4.9$ (two estimated standard deviations $=2 \mathrm{ESD}$ ) $\mathrm{kJ} / \mathrm{mol}$ (Table 7) is obtained for orthopyroxene using $a / X$ relations of Andersen et al. (1991) for ilmenite. A similar value for $W_{G}^{\text {opx }}$ of $4.8 \pm 5.8$ (2 ESD) $\mathrm{kJ} / \mathrm{mol}$ is obtained using ilmenite mixing relations of Ghiorso (1990).

The assumption that $W_{G}^{\mathrm{Opx}}=W_{H}^{\mathrm{opx}}$ for iron-magnesium orthopyroxene is supported by simultaneous consideration of all available data on mixing relations of orthopyroxene (Fig. 7), including phase equilibrium experiments (Nafziger and Muan 1967; Kitayama and Katsura 1968; Kitayama 1970; Koch-Müller et al. 1992; von Seckendorff and O'Neill 1993; this study), enthalpy of solution measurements (Chatillon-Colinet et al. 1983), site occupancy data (Virgo and Hafner 1969; Saxena and Ghose 1971; Besancon 1981; Anovitz et al. 1988; Saxena et al. 1989; Molin et al. 1991; Domeneghetti and Steffen 1992), and theoretical calculations (Navrotsky 1971; Sack and Ghiorso 1989). Figure seven is a compilation of $W_{G}^{\mathrm{Opx}}$ calculated for $\mathrm{FeSiO}_{3}-\mathrm{MgSiO}_{3}$ orthopyroxene between $500-1300^{\circ} \mathrm{C}$ from a symmetric solution model. All of the data combined are consistent with the assumption that $W_{G}^{\mathrm{opx}}$ is independent of temperature (regular solution model, $W_{S}^{\mathrm{Opx}}=0$ ) and yield an average value for $W_{G}^{\text {opx }}$ of $4.5 \mathrm{~kJ} / \mathrm{mol}$. Equations 3 and $8-11$ of Saxena and Ghose (1971) were used to calculate $W_{G}^{\text {Opx }}$ from site occupancy data determined from Mössbauer and X-ray refinement studies in the literature. All X-ray data were combined (Saxena et al. 1989; Molin et al. 1991; Sykes and Molin - personal communication to Shi et al. 1992; Domeneghetti and Steffen 1992) because data from each study were not sufficient for regression analysis. Multiple regression of the combined X-ray data yields a value for $W_{G}^{\text {Opx }}$ of $3 \pm 2(2 \mathrm{ESD}) \mathrm{kJ} / \mathrm{mol}$ that is consistent with the data shown in Fig. 7. Mössbauer data from Besancon (1981) were insufficient for regression analysis and are excluded from Fig. 7, as were the

Table 7. Excess terms for binary orthopyroxene (in kilojoules)

\begin{tabular}{|c|c|c|c|c|}
\hline & $\mathrm{W}_{\mathbf{H}}^{\mathrm{ABL}}$ & $\mathrm{W}_{\mathrm{H}}^{\mathrm{G}}$ & $W_{s}{ }^{a}$ & $W_{v}^{b}$ \\
\hline \multicolumn{5}{|c|}{ Symmetric } \\
\hline $\begin{array}{l}W \\
W^{(1)}\end{array}$ & $\begin{array}{l}3.6(4.9) \\
4.5(1.5)\end{array}$ & $\begin{array}{l}4.8(5.8) \\
5.2(1.4)\end{array}$ & $\begin{array}{l}0.0 \\
0.0\end{array}$ & $\begin{array}{l}0.0 \\
0.0\end{array}$ \\
\hline \multicolumn{5}{|c|}{ Asymmetric } \\
\hline $\begin{array}{l}W_{\text {EnFs }} \\
W_{F s E n}\end{array}$ & $\begin{array}{l}2.3(20.1) \\
4.5(16.3)\end{array}$ & $\begin{array}{l}4.1(23.2) \\
5.4(18.6)\end{array}$ & $\begin{array}{l}0.0 \\
0.0\end{array}$ & $\begin{array}{l}0.0 \\
0.0\end{array}$ \\
\hline $\begin{array}{l}W_{\mathrm{EnFs}^{(1)}}^{(1)} \\
W_{\mathrm{FsEn}}^{(1)}\end{array}$ & $\begin{array}{l}4.6(1.8) \\
4.4(9.2)\end{array}$ & $\begin{array}{l}5.2(1.6) \\
5.5(8.1)\end{array}$ & $\begin{array}{l}0.0 \\
0.0\end{array}$ & $\begin{array}{l}0.0 \\
0.0\end{array}$ \\
\hline
\end{tabular}

$W_{G}=W_{H}-T W_{S}+P W_{V}$

Values for a symmetric model are from least-squares fits to $\mathrm{Eq}$. (4) (cf. text for asymmetric model). Uncertainties ( \pm 2 ESD) in parentheses, including $\pm 1 \mathrm{~mol} \%$ in compositions. $W^{(1)}$, calculated relative to the location of equilibrium (1) of Berman (1988). ABL, based on the activity model for ilmenite of Andersen et al. (1991); $\mathrm{G}$, based on the activity model for ilmenite of Ghiorso (1990) a All excess entropy terms are assumed to be zero (cf., Fig. 7)

b All excess volume terms are assumed to be zero based on powder $\mathrm{X}$-ray diffraction of synthetic orthopyroxene used in this study and values obtained on synthetic orthopyroxene reported in the literature (cf., Fig. 6) 


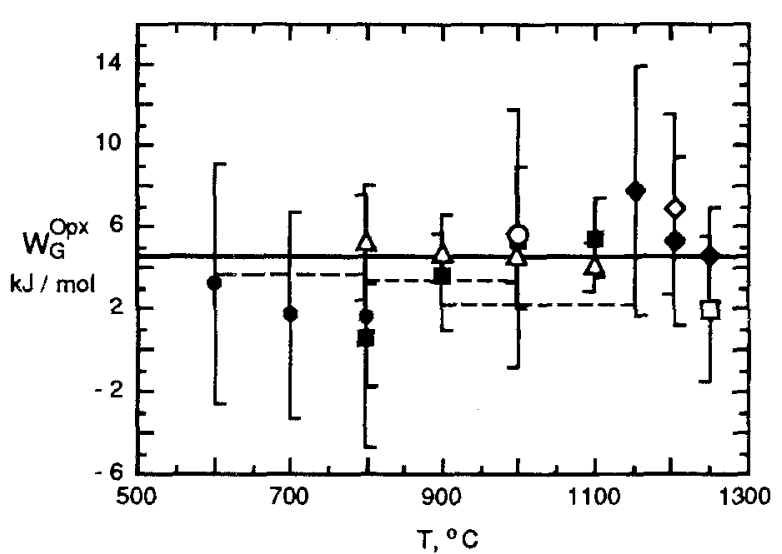

Fig. 7. Plot of $W_{\mathrm{G}}^{\mathrm{Opx}}$ versus $\mathrm{T}$ for $\mathrm{FeSiO}_{3}-\mathrm{MgSiO}_{3}$ orthopyroxene. Filled squares are data from this study, calculated from Eq. (4) based on $a / X$ relations for ilmenite of Andersen et al. (1991). Filled triangles are calculated from data in this study relative to the locus of equilibrium (1) as a reference (Berman 1988), also using $a / X$ relations for ilmenite of Andersen et al. (1991). Other data are from: Nafziger and Muan (1967), open square; Kitayama and Katsura (1968), open diamond; Virgo and Hafner (1969), open circle; Kitayama (1970), filled diamonds; Saxena and Ghose (1971), filled circles. Dashed horizontal lines represent values obtained by Anovitz et al. $\left(1988,600-800^{\circ} \mathrm{C}\right)$, Koch-Müller et al. $\left(1992,800-1000^{\circ} \mathrm{C}\right)$ and von Seckendorff and O'Neill $\left(1993,900-1150^{\circ} \mathrm{C}\right)$. Heavy horizontal line represents an average $W_{G}^{\mathrm{opx}}$ of $4.5 \mathrm{~kJ} / \mathrm{mol}$ for all the data shown

Mössbauer results of Skogby (1992) for natural samples that contain significant amounts of other components. Calculations of Navrotsky (1971) predict that mixing relations in orthopyroxene should be nearly ideal. Sack and Ghiorso (1989) calculated mixing relations in orthopyroxene using a thermodynamic model that makes explicit provision for non-convergent ordering of iron and magnesium between the M1 and M2 sites and that accounts for a non-zero Gibbs energy of the reciprocal ordering reaction; their $a / X$ relations are consistent with our results.

The Sirf data were also fit to an asymmetric binary solution model. Solution of the appropriate equation (Thompson 1967) for $W_{G}^{\mathrm{EnFs}}$ (enstatite on the binary join) and $W_{G}^{\mathrm{FsEn}}$ (ferrosilite) as a function of temperature, using the same thermodynamic data and assumptions as for the symmetric model, predicts a concomitant increase in $W_{G}^{\mathrm{EnFs}}$ and decrease in $W_{G}^{\mathrm{FEEn}}$ with increasing temperature. The thermodynamic equations involve the summation of small numbers, and slight changes dramatically affect the calculated $W$ parameters. Neither interaction parameter shows a systematic variation as a function of temperature, and the Sirf data are not sufficient to allow determination of a temperature dependence of $W_{G}^{\mathrm{EnFs}}$ and $W^{\mathrm{FsEn} G}$ because of the large errors involved in the calculations. Use of an asymmetric solution model, which involves two unknown interaction parameters, reduces the amount of independent experimental data because it requires three (versus two) experimental reversals to obtain solutions for $W_{G}^{\mathrm{EnFs}}$ and $W_{G}^{\mathrm{FsEn}}$. Assuming no temperature dependence $\left(W_{G}=W_{H}\right)$ for an asymmetric model, $W_{G}^{\mathrm{EnFs}} \approx 3 \pm 22 \mathrm{~kJ} / \mathrm{mol}$ and $W_{G}^{\mathrm{FsEn}} \approx 5 \pm 17 \mathrm{~kJ} / \mathrm{mol}$ ( 2 ESD, Table 7). These values are similar to values obtained assuming a symmetric model and use of the more complex asymmetric model is not justified, given the large errors.

\section{Comparison with Tweeq}

The locus of equilibrium (1) calculated with the Tweeq program of Berman (1991) from thermodynamic data of Berman (1988) was also used in conjunction with the Sirf data to determine mixing relations in orthopyroxene. Equation (4) was solved for $W_{G}^{\text {opx }}$ relative to the pure ferrosilite end-member (1) using $P-T-X$ data from our experiments (with an $a_{\mathrm{TiO}_{2}}^{\mathrm{Rut}}=0.98$ ) for the temperature range $800-1100^{\circ} \mathrm{C}$. Values of $W_{G}^{\text {Opx (1) }}$ calculated in this manner decrease regularly with increasing temperature, although the temperature dependence is small. A $W_{G}^{\mathrm{Opx}(1)}=W_{H}^{\mathrm{Opx}(1)}$ of $4.5 \pm 1.5(2 \mathrm{ESD}) \mathrm{kJ} / \mathrm{mol}$ is obtained for orthopyroxene, based on the ilmenite model of Andersen et al. (1991), and a $W_{G}^{\mathrm{Opx}(1)}=W_{H}^{\mathrm{Opx}(1)}$ of $5.2 \pm 1.4$ (2 ESD) $\mathrm{kJ} / \mathrm{mol}$ is obtained from the ilmenite model of Ghiorso (1990) (Table 7). The results are consistent with values for $W_{G}^{\mathrm{Opx}}$ of $3.6 \pm 4.9$ (2 ESD) $\mathrm{kJ} / \mathrm{mol}$ (ilmenite model of Andersen et al. 1991) and 4.8 \pm 5.8 (2 ESD) $\mathrm{kJ} / \mathrm{mol}$ (ilmenite model of Ghiorso 1990) generated internally from the experiments.

The validity of a symmetric model can be tested by solving Eq. (4) for $P_{1}$, where $P_{1}$ equals the locus of the iron end-member (1), using a range of $W_{G}^{\mathrm{Opx}}$ of $4-5 \mathrm{~kJ} /$ mol (Table 7), $P-T-X$ data from the experiments and volume data of Berman (1988). The loci of equilibrium (1) calculated in this manner agree with that determined by the Tweeq program (Berman 1988; Berman 1991) within about $2 \mathrm{kbar}$, indicating that a symmetric model is adequate (given the large errors in $W$ parameters) to describe mixing relations for binary $\mathrm{FeSiO}_{3}-\mathrm{MgSiO}_{3}$ orthopyroxene.

\section{Derived a/X relations of orthopyroxene}

Data from this study indicate that $\mathrm{FeSiO}_{3}-\mathrm{MgSiO}_{3}$ orthopyroxene exhibits small deviations from ideality that are probably positive, but within error may be zero or even slightly negative. Activity coefficients for ferrosilite (for $X_{\mathrm{FeSiO}_{3}}^{\mathrm{Opx}}=0.3-0.7$ ) calculated from excess parameters and a symmetric mixing model (Table 7) range from 1.22-1.03 (ilmenite $a / X$ from Andersen et al. 1991) to 1.30-1.04 (ilmenite $a / X$ from Ghiorso 1990). Activitycomposition relations for ferrosilite based on $P-T-X$ data from this study, ilmenite mixing relations of Andersen et al. (1991) and a symmetric solution model are plotted in Fig. 8. Activity-composition relations at 800 $1100^{\circ} \mathrm{C}$ based on the ilmenite model of Ghiorso (1990) are similar.

Results from this study are in agreement with $a / X$ relations determined for $\mathrm{FeSiO}_{3}-\mathrm{MgSiO}_{3}$ orthopyroxene by Nafziger and Muan (1967) at $1250^{\circ} \mathrm{C}$, Kitayama (1970) at $1150-1250^{\circ} \mathrm{C}$, Saxena and Ghose (1971) at 600$800^{\circ} \mathrm{C}$, Koch-Müller et al. (1992) at $800-1000^{\circ} \mathrm{C}$, and agree with calculations by Sack and Ghiorso (1989) and Shi et al. (1992) for the temperature ranges $500-1300^{\circ} \mathrm{C}$ and $500-1000^{\circ} \mathrm{C}$, respectively. 


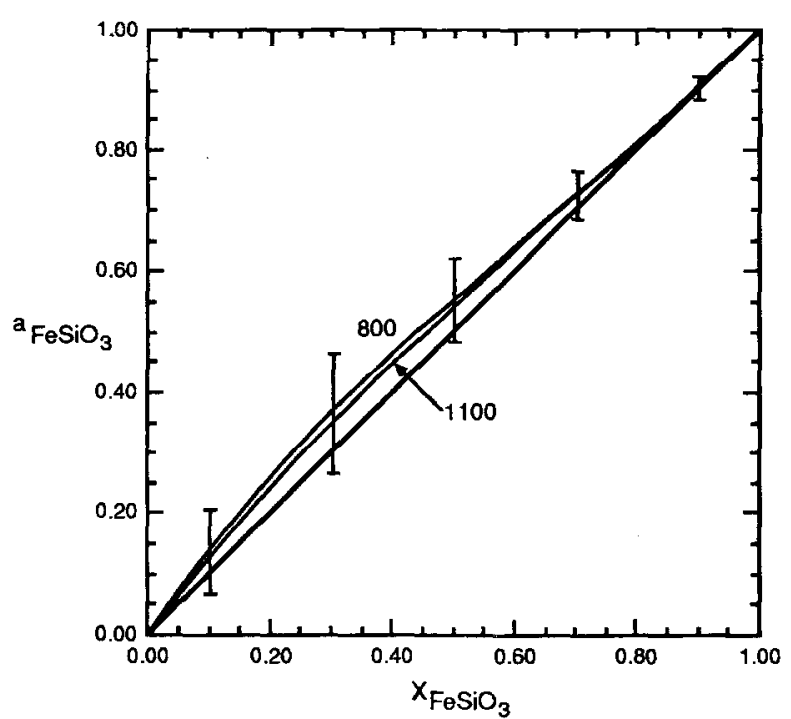

Fig. 8. Activity-composition relations for ferrosilite calculated from experimental results of this study. Curves are shown for 800 and $1100^{\circ} \mathrm{C}$ assuming a symmetric regular solution model with a $W_{G}^{\mathrm{Opx}}$ of $3.6 \mathrm{~kJ} / \mathrm{mol}$ (based on the ilmenite model of Andersen et al. 1991). Error bars for activity are $2 \mathrm{ESD}$ and estimated error in composition is $\pm 1 \mathrm{~mol} \%$

Sharma et al. (1987) calculated $a / X$ relations in orthopyroxene at $727^{\circ} \mathrm{C}$ based on emf measurements of the equilibrium between ferrosilite, iron metal and quartz. Their results suggest that binary orthopyroxene shows positive deviations from ideality that are larger than those indicated by this study, but their errors in mixing relations are also large $\left( \pm 0.092 \mathrm{ESD}\right.$ in $\left.a_{\mathrm{FeSiO}}^{\mathrm{Opx}}\right)$. Sharma et al. (1987) calculated a $\Delta \mathrm{G}_{1000 \mathrm{~K}}^{0} f$ of ferrosilite from the oxides that is $4-5 \mathrm{~kJ} / \mathrm{mol}$ lower than recent estimates (Anovitz and Essene 1987; Berman 1988). Pyroxene used in their experiments was synthesized at 1 bar and $1200^{\circ} \mathrm{C}$, but it is not certain that the orthorhombic structure was produced (e.g., Turnock et al. 1973) or what the actual compositions were. Some ironrich olivine should have been produced in synthesis of orthopyroxene of $X_{\mathrm{FeSiO}} \mathrm{Opx}_{3}=0.77$ and 0.90 at $1200^{\circ} \mathrm{C}$ and $1 \mathrm{~atm}$ (Nafziger and Muan 1967), and olivine may have formed metastably in more magnesian compositions (e.g., this study). The significance of the emf measurements in the presence of two ferromagnesian silicates is difficult to evaluate. The experiments and $a / X$ relations of Sharma et al. (1987) for orthopyroxene have therefore been disregarded in this study.

Isopleths of $1 / K$ relative to the iron end-member (1) and $X_{\mathrm{FeSiO}_{3}}^{\mathrm{Opx}}$ determined for the range of $P-T-X$ conditions studied are contoured in Fig. $9 \mathrm{a}$ and b. The equilibrium constant was calculated from $K=\left[a_{\mathrm{FeTiO}_{3}}^{\mathrm{llm} /}\right.$ $\left.\left(a_{\mathrm{FeSiO}}^{\mathrm{ppx}} \cdot a_{\mathrm{TiO}_{2}}^{\mathrm{Rut}}\right)\right]$ for $a_{\mathrm{FeTiO}_{3}}^{\mathrm{nlm}}=1.0$ and $a_{\mathrm{TiO}_{2}}^{\mathrm{Rut}}=0.98(1 / K$ $\left.=0.98 \cdot a_{\mathrm{FeSiO}}^{\mathrm{Opx}}\right)$. Activities of $\mathrm{FeSiO}_{3}$ in orthopyroxene were calculated from Eq. (4) and the relation $R T \ln \gamma_{\mathrm{FeSiO}_{3}}^{\mathrm{Opx}}=\left(X_{\mathrm{En}}\right)^{2} W_{\mathrm{G}}^{\mathrm{Opx}}$. All isopleths of $X_{\mathrm{FeSx}_{3}}^{\mathrm{Opx}}$ were corrected for the effects of solid solution of magnesium in ilmenite (i.e., $a_{\mathrm{FeTiO}_{3}}^{\mathrm{nlm}}=1.0$ ) to allow a more direct comparison between the measured $\left(X_{\mathrm{FeSP}_{3}}^{\mathrm{Opx}}\right)$ and calculated positions $\left(a_{\mathrm{FeSiO}_{3}}^{\mathrm{Opx}}\right)$ of the curves. The effect of this correction is to shift the isopleths of $X_{\mathrm{FeSiO}_{3}}^{\mathrm{Opx}}$ toward lower pressure and to rotate them toward lower pressure at higher temperature where solid solution of magnesium in ilmenite is greater. In Fig. 9 a, the ilmenite model of Andersen et al. (1991) was used to correct the isopleths of $X_{\mathrm{FeSiO}}^{\mathrm{Opx}}$ to a unit activity of ilmenite, and in Fig. $9 \mathrm{~b}$ the model of Ghiorso (1990) was used. The ilmenite model of Andersen et al. (1991) is more ideal than the model of

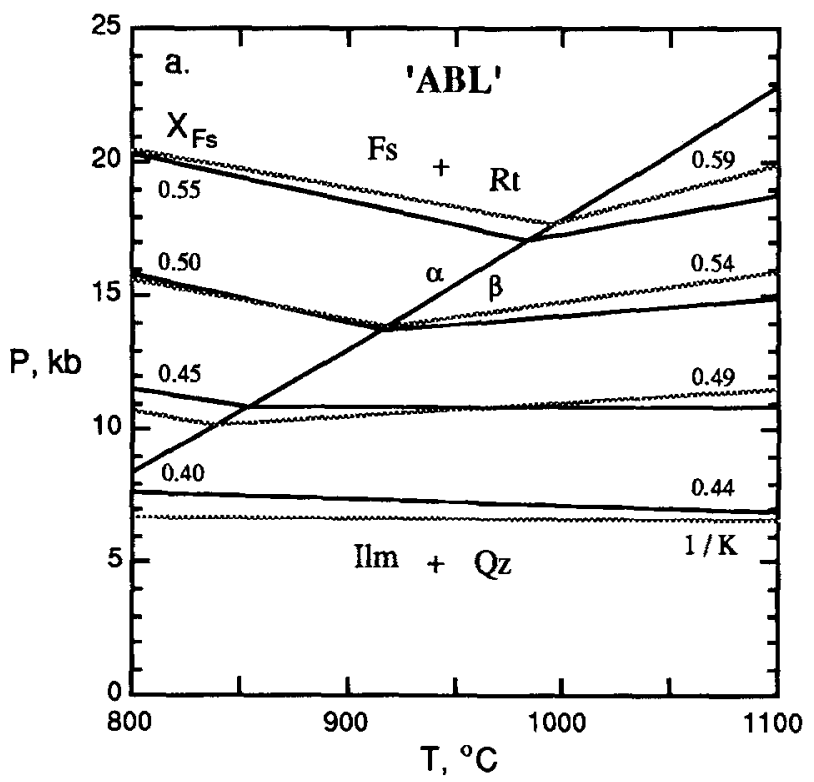

Fig. 9a, b. Pressure-temperature diagrams that show isopleths of $X_{\mathrm{FeSiO}_{3}}^{\mathrm{Opx}}\left(X_{\mathrm{Fs}}\right.$, heavy curves) determined from the Sirf experiments and isopleths of $1 / \mathrm{K}$ for equilibrium (1), light curves, where $K$ $=a_{\mathrm{Ilm}} /\left(a_{\mathrm{Fs}} a_{R t}\right)$, calculated from a symmetric regular solution model using values of $W_{G}^{\text {Opx }}$ from Table 5. All curves are corrected to an $a_{\mathrm{FeTiO}_{3}}^{\mathrm{IIm}}=1.0$. a Isopleths of $X_{\mathrm{Fs}}$ are corrected to unit activity

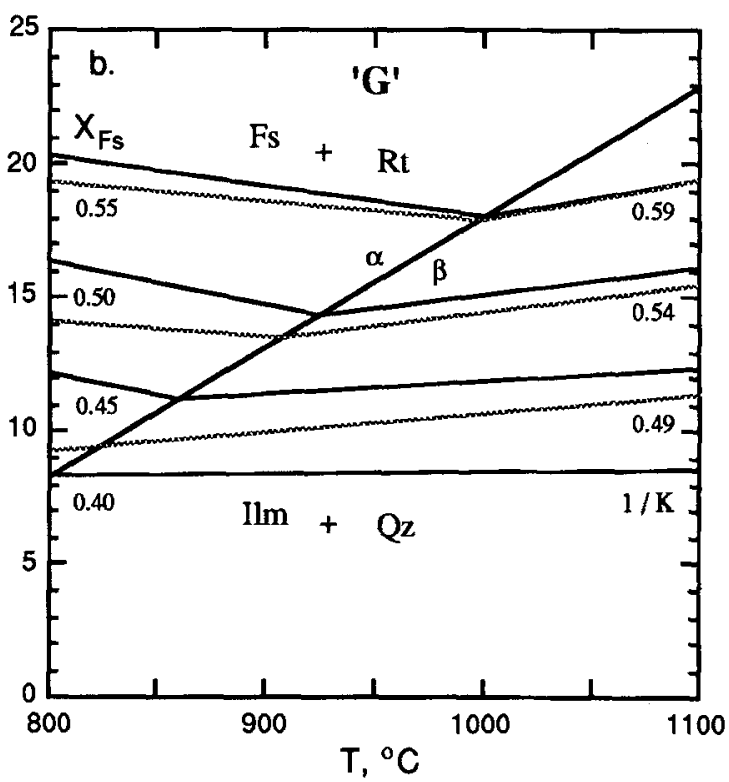

of ilmenite using the model of Andersen et al. (1991) and isopleths of $1 / \mathrm{K}$ are calculated from a $\mathrm{W}^{\mathrm{ABL}}$ of $3.6 \mathrm{~kJ} / \mathrm{mol}$ for orthopyroxene. b Isopleths are determined in the same manner as a using the ilmenite model of Ghiorso (1990) and a $\mathrm{W}^{\mathrm{G}}$ of $4.8 \mathrm{~kJ} / \mathrm{mol}$ for orthopyroxenc. $\alpha \mathrm{Qz}=\beta \mathrm{Qz}$ from Cohen and Klement (1967) 
Ghiorso (1990) and the isopleths of $X_{\mathrm{FeSiO}_{3}}^{\mathrm{Opx}}$ are shifted to lower pressures in Fig. 9 a. Andersen et al. (1991) use a temperature-dependent asymmetric model for ilmenitehematite-geikielite solutions in composition space, whereas the model of Ghiorso (1990) makes explicit provision for convergent cation ordering and uses temperatureindependent, symmetric regular solution parameters to describe the energetics of mixing between joins in composition-ordering space. For compositions of ilmenite products in the Sirf experiments $\left(X_{\mathrm{FeTiO}_{3}}^{\mathrm{Ilm}}>0.85\right)$, the difference in $a_{\mathrm{FeTiO}_{3}}^{\mathrm{Im}}$ calculated with the two models is small at $800-1100^{\circ} \mathrm{C}$ (cf., Ghiorso and Sack 1991).

Isopleths of $K$ calculated from the Sirf data (Fig. 9a, b) are in agreement within 1 kbar between $900-1100^{\circ} \mathrm{C}$ with isopleths of $K$ calculated from the Tweeq program (Berman 1991) using data from Berman (1988). At $800^{\circ} \mathrm{C}$, isopleths of $K$ agree within $2-3 \mathrm{kbar}$. Given possible errors in thermodynamic data, ilmenite models or measurements of the variables $P-T-X$, the agreement is quite good. Berman's most recent data base (1990) incorporates modifications in the thermodynamic properties of almandine and includes a decrease of $0.5 \mathrm{~kJ} /$ mol for the $A \mathrm{H}_{298}^{0} f$ of ilmenite. This change in the enthalpy of ilmenite shifts the calculated locus of equilibrium (1) to pressures that are approximately $3 \mathrm{kbar}$ greater than shown in Fig. 1 and increases the discrepancy with the Sirf results for isopleths of the equilibrium constant.

\section{Potential for thermobarometry}

Experimental results from this study on the Sirf equilibria were used to estimate pressures of equilibration and to test the attainment of equilibrium between coexisting pairs of orthopyroxene and ilmenite for natural samples. Pressures were estimated for orthopyroxene-rutile granulites from the Grenville Province of Ontario (Anovitz 1987; Anovitz and Essene 1990) and for granulite facies xenoliths from central Mexico (Table 8). Granulites from the Grenville Province contain (Anovitz 1987): garnet + clinopyroxene + orthopyroxene + plagioclase/antiperthite + quartz + biotite + amphibole + ilmenite + apatite + rutile (in garnet only) (ROS-83C-2), clinopyroxene + orthopyroxene + plagioclase + quartz + biotite + amphibole + rutile + ilmenite (ROS-83C-16), and garnet + clinopyroxene + orthopyroxene + plagioclase + amphibole + ilmenite/hematite + magnetite + apatite with inclusions of quartz + rutile in garnet (ROS-83C21). Hayob et al. (1989) presented thermobarometric data for paragneiss xenoliths from three localities in central Mexico. Here, we present data for orthogneiss xenoliths from Los Palau and La Joya Honda that contain the assemblages: garnet + orthopyroxene + plagioclase + rutile + ilmenite + rutile/ilmenite rims + minor quartz (LP-16), clinopyroxene + orthopyroxene + plagioclase + rutile + rutile/ilmenite rims + apatite (LJH-16), and garnet + quartz + orthopyroxene + plagioclase + alkali feldspar + rutile + ilmenite + rutile/ilmenite rims + graphite (LJH-30). Chemical analyses of coexisting orthopyroxene and ilmenite were obtained with the Cameca elec- tron microprobe at the University of Michigan for the Mexican samples and sample ROS-83C-16. Operating conditions were the same as for the experimental materials. Electron microprobe analyses are not presented in this paper because of space limitations; data may be obtained from the authors upon request. Chemical data for other samples from the Grenville Province are given in Anovitz (1987).

The equilibrium distribution of iron and magnesium between orthopyroxene and ilmenite determined from our experiments can be used to qualitatively assess temperatures of equilibration and the attainment of equilibrium for natural samples. Figure $10 \mathrm{a}$ is a composition diagram that shows $\mathrm{Fe} / \mathrm{Mg}$ distribution data determined from our experiments as a function of temperature. Both ilmenite and orthopyroxene become enriched in iron with increasing pressure (i.e., through a heterogeneous equilibrium involving solid solutions), but values of the $K_{D}$ are independent of pressure for equilibrium (3).

Data for natural samples are shown in Fig. 10b. Data from our experiments on the $K_{D}$ suggest that some of the natural ilmenite was not in equilibrium with coexisting orthopyroxene. Ilmenite compositions in exposed rocks from the Grenville Province typically are reset to lower temperatures even when reintegrated ilmenite analyses are used (Anovitz and Essene 1990). Ilmenite and orthopyroxene are both homogeneous in a given sample, but values of $K_{D}$ are much higher than predicted from our experimental data at $800^{\circ} \mathrm{C}$. Diffusion of iron and magnesium appears to be more rapid in ilmenite than in orthopyroxene based on the lack of zoning in all ilmenite starting materials and products examined in this study. The susceptibility of ilmenite to loss of magnesium upon even rapid cooling after the peak of metamorphism has been noted by Frost and Lindsley (1992). Garnetpyroxene and two-feldspar thermometry (Anovitz 1987; Anovitz and Essene 1990) indicate that peak metamorphic temperatures were $750 \pm 50^{\circ} \mathrm{C}$, at least one hundred degrees higher than temperatures estimated from ilmenite-orthopyroxene $K_{D}$ exchange (Fig. 10b). In contrast, some ilmenite in granulite facies xenoliths from central Mexico show a large range in composition from grain to grain, while orthopyroxene is not zoned within a given sample. It is unlikely that the orthopyroxene compositions would be so uniform if they had been affected by retrogression and/or transport processes. Ilmenite that is reset to higher temperatures occurs as rims on rutile and probably formed during decompression. Garnet-orthopyroxene, two-pyroxene and two-feldspar thermometry suggest peak metamorphic temperatures of 950 $1050^{\circ} \mathrm{C}$. Thus, ilmenite is not suitable for use in peak $K_{D}$ thermometry (cf., Frost and Lindsley 1992). Ilmenite may be useful for barometry, however, if the barometers are robust to moderate variations in ilmenite composition. For natural samples in which ilmenite appears to have been altered, isotherms from Fig. 10a can be used to estimate the composition of the ilmenite that should have been in equilibrium with orthopyroxene at a given temperature, if it can be assumed that the composition of the orthopyroxene was preserved from the peak of metamorphism. 


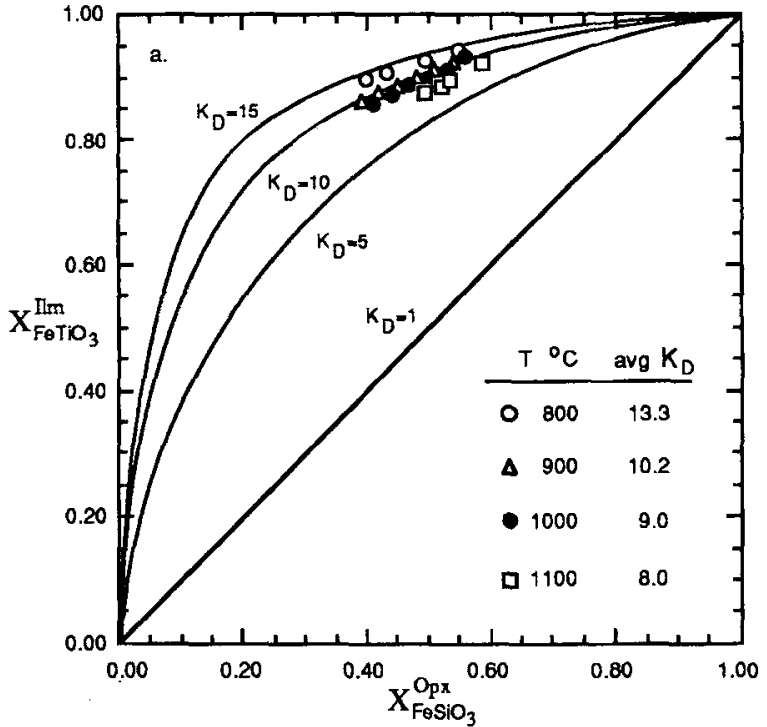

Fig. 10. a Equilibrium distribution of iron and magnesium between ilmenite and orthopyroxene determined from this study at 800 $1100^{\circ} \mathrm{C} . \quad K_{D}=(\mathrm{Mg} / \mathrm{Fe})^{\mathrm{opx}} /(\mathrm{Mg} / \mathrm{Fe})^{\mathrm{iim}}$, estimated error is \pm 0.5 . Curves are calculated for $K_{D} \mathrm{~s}$ of $1,5,10$ and 15. b Distribution of iron and magnesium between natural pairs of coexisting ilmenite

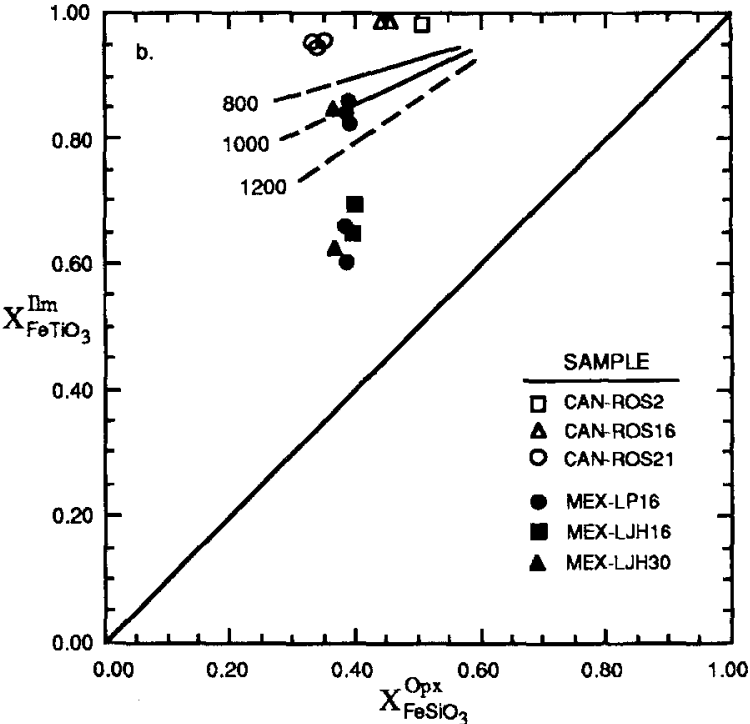

and orthopyroxene compared to isotherms estimated from a. Pairs from an exposed metamorphic terrane are shown as open symbols (Grenville, Anovitz and Essene 1990). Pairs from xenolith localities are shown as filled symbols (Mexico, this study, cf., Hayob et al. 1989). $X_{\mathrm{FeTiO}_{3}}^{\mathrm{Mmm}}$ and $X_{\mathrm{FeSiO}}^{\mathrm{Opx}}=\mathrm{Fe}^{2+} /\left(\mathrm{Fe}^{2+}+\mathrm{Mg}\right)$

Table 8. Thermobarometric calculations for the Rosseau domain, Grenville Province of Ontario, Canada (Anovitz 1987; Anovitz and Essene 1990) and xenoliths from central Mexico (this study)

\begin{tabular}{|c|c|c|c|c|c|c|c|c|c|c|c|}
\hline \multirow[t]{2}{*}{ Sample no. } & & \multirow[t]{2}{*}{$X_{\mathrm{FeSiO}_{3}}^{\mathrm{Opx}}$} & \multirow[t]{2}{*}{$X_{\mathrm{MgSiO}_{3}}^{\mathrm{Opx}}$} & \multirow[t]{2}{*}{$X_{\mathrm{FeTiO}_{3}}^{\mathrm{Ilm}}$} & \multirow[t]{2}{*}{$X_{\mathrm{MgTiO}_{3}}^{\mathrm{Ilm}}$} & \multicolumn{3}{|c|}{ Pressure $( \pm 0.5 \mathrm{kbar}$, excluding Sirf) } & \multicolumn{3}{|c|}{ Temperature $\left( \pm 50^{\circ} \mathrm{C}\right)$} \\
\hline & & & & & & Gafs $^{d}$ & Grips $^{e}$ & Sirf & Gt-Opx ${ }^{\mathrm{f}}$ & Gt-Cpx ${ }^{\mathrm{g}}$ & 2Feldspar ${ }^{h}$ \\
\hline MEX-LP & 16 & 0.36 & 0.59 & 0.82 & 0.16 & 12.2 & 11.7 & $10-15$ & 950 & & \\
\hline
\end{tabular}

Average $P-T$ for Rosseau domain $\sim 10 \mathrm{kbar}$ (excluding Sirf) and $750^{\circ} \mathrm{C}$ (excluding $910^{\circ} \mathrm{C}$ value) (Anovitz and Essene 1990); average $P-T$ for xenoliths from Mexico $\sim 11.5 \mathrm{kbar}$ (excluding Sirf) and $1000^{\circ} \mathrm{C}$

a $P-T-X$ from Anovitz and Essene (1990), excluding Sirf. Mole fractions are average values

b Ilmenite occurs only as rims on rutile; lower $P$ limit calculated assuming a unit activity for ilmenite

c Based on ilmenite compositions at the peak of metamorphism predicted from $800^{\circ} \mathrm{C}$ isotherm of Fig. $10 \mathrm{a}$ (cf., text)

Pressures were calculated using the Sirf equilibrium (1) by comparing values of $K$ for natural assemblages with calculated values of $K$ contoured in $P-T$ space (Fig. 9a, b). A single equation cannot be used to describe the loci of the isopleths (for a given ilmenite model), which have slopes that vary as a function of $P$ and $T$. Errors in pressure introduced from a graphical solution are small compared to errors in the activity models that were used to generate the isopleths. Values of $K$ for the natural assemblages were calculated using our values of $W_{G}^{\text {opx }}$ (dependent on ilmenite, Table 7) to calculate the activity of ferrosilite at $T$, determined independently (Ta- d $\mathrm{CaFe}_{2} \mathrm{Al}_{2} \mathrm{Si}_{3} \mathrm{O}_{12}+\mathrm{SiO}_{2}=\mathrm{CaAl}_{2} \mathrm{Si}_{2} \mathrm{O}_{8}+\mathrm{Fe}_{2} \mathrm{Si}_{2} \mathrm{O}_{6}$ (Bohlen et al. 1983a)

e $\mathrm{CaFe}_{2} \mathrm{Al}_{2} \mathrm{Si}_{3} \mathrm{O}_{12}+2 \mathrm{TiO}_{2}=2 \mathrm{FeTiO}_{3}+\mathrm{CaAl}_{2} \mathrm{Si}_{2} \mathrm{O}_{8}+\mathrm{SiO}_{2}$ (Bohlen and Liotta 1986)

f $2 \mathrm{Fe}_{3} \mathrm{Al}_{2} \mathrm{Si}_{3} \mathrm{O}_{12}+3 \mathrm{Mg}_{2} \mathrm{Si}_{2} \mathrm{O}_{6}=2 \mathrm{Mg}_{3} \mathrm{Al}_{2} \mathrm{Si}_{3} \mathrm{O}_{12}+3 \mathrm{Fe}_{2} \mathrm{Si}_{2} \mathrm{O}_{6}$ (Sen and Bhattacharya 1984)

g $\mathrm{Fe}_{3} \mathrm{Al}_{2} \mathrm{Si}_{3} \mathrm{O}_{12}+3 \mathrm{CaMgSi}_{2} \mathrm{O}_{6}=\mathrm{Mg}_{3} \mathrm{Al}_{2} \mathrm{Si}_{3} \mathrm{O}_{12}+3 \mathrm{CaFeSi}_{2} \mathrm{O}_{6}$ (Ellis and Green 1979)

h $X_{\mathrm{Ab}}$ (plagioclase) $-X_{\mathrm{Ab}}$ (Kfeldspar) (ROS, Haselton et al. 1983; MEX, Lindsley and Nekvasil 1989)

i Two-pyroxene thermometry (Lindsley 1983)

ble 8), from $R T \ln \gamma_{\mathrm{FeSiO}_{3}}^{\mathrm{Opx}}=\left(X_{\mathrm{En}}\right)^{2} W_{G}^{\mathrm{Opx}}$. The model-dependent activity of ferrosilite was combined with the appropriate activity of ilmenite, and an ideal model was used for the activity of rutile. Pressures estimated from the Sirf equilibria are compared to pressures calculated from the Gafs (Bohlen et al. 1983a) and Grips (Bohlen and Liotta 1986) barometers in Table 8.

Pressures calculated from the Sirf equilibria for the xenoliths from central Mexico are consistent with values estimated from the Gafs and Grips barometers (Table 8). All three xenoliths contain rutile $\left(a_{\mathrm{TiO}_{2}}^{\mathrm{Rut}}=0.98\right)$ that is partially rimmed by ilmenite. In sample LJH-16, all ilmenite 
occurs as partial rims on rutile. In the other two xenoliths, a few discrete crystals of ilmenite occur in the matrix (LP-16) and as inclusions in garnet (LP-16 and $\mathrm{LJH}-$ 30). The discrete ilmenite is richer in iron than ilmenite that rims rutile and appears to have been in equilibrium with orthopyroxene at about $1000^{\circ} \mathrm{C}$ (Fig. 10 b). Discrete ilmenite was used for all calculations with the Grips barometer. Pressures estimated from Sirf using ilmenite that rims rutile are anomalously high ( $>20 \mathrm{kbar}$ ). Ilmenite that rims rutile probably formed during rapid decompression accompanied by heating as the xenoliths were transported to the surface (Fig. 10b).

Although textures in sample ROS-83C-16 suggest that ilmenite may have been in equilibrium with orthopyroxene (Fig. $2 a$ ), $K_{D}$ data from the Sirf experiments indicate that the ilmenite and orthopyroxene could not have been in equilibrium at the peak of metamorphism $\left(\sim 800^{\circ} \mathrm{C}\right.$, Anovitz and Essene 1990, Fig. 10b). Orthopyroxene is unzoned in this sample and no ferric iron is indicated in ilmenite from electron microprobe analysis. Pressures estimated from Sirf are in agreement with regional estimates of $9.5-11.5 \mathrm{kbar}$ based on Gafs and Grips (Table 8, Anovitz and Essene 1990). However, this agreement is probably fortuitous as unreasonably high pressures $(\sim 19 \mathrm{kbar})$ are calculated from Sirf using ilmenite compositions predicted from the $K_{D}$ data at $800^{\circ} \mathrm{C}$.

Other samples for which Sirf results are anomalous compared to Gafs and Grips contain ilmenite with a substantial hematite component. Ilmenite from sample ROS- $83 \mathrm{C}-2$ contains about 9 mol\% hematite component, and it occurs in the matrix and as inclusions in garnet. No evidence of exsolved hematite was observed with Bse imaging. A few grains of rutile occur as inclusions in garnet. Orthopyroxene, occurring only in the matrix, contains $<4 \mathrm{~mol} \%$ of non-quadrilateral components $(\sim 2 \mathrm{~mol} \%$ each of $\mathrm{Ca}$ and $\mathrm{Mn})$ and appears to have been in equilibrium with ilmenite in the matrix. Pressures that are consistent with regional estimates are obtained from Gafs and Grips (Table 8), but anomalously high pressures are determined from Sirf. Isotherms in Fig. 10 a can be used to estimate the iron number $\left[\mathrm{Fe}\right.$ no. $\left.=\mathrm{Fe}^{2+} /\left(\mathrm{Fe}^{2+}+\mathrm{Mg}\right)\right]$ of ilmenite that should have been in equilibrium with orthopyroxene at the peak of metamorphism, and the mole fraction of $\mathrm{FeTiO}_{3}$ in ilmenite for the peak of metamorphism can be calculated by assuming that the mole fraction of hematite has remained constant. Activities of $\mathrm{FeTiO}_{3}$ in ilmenite can then be calculated from the appropriate activity models (Ghiorso 1990; Andersen et al. 1991). Pressures calculated from Sirf using predicted compositions of ilmenite are also anomaloiusly high compared to regional estimates (Table 8). In sample ROS-83C-21, a few ilmenite grains occur in the matrix and as inclusions in garnet that contain exsolved hematite. Rutile occurs in the matrix and as inclusions in garnet. A pressure of $9.4 \mathrm{kbar}$ (Anovitz and Essene 1990), consistent with regional estimates, is obtained from Gafs. Values of $K_{D}$ indicate that the $\mathrm{Fe}$ no. of the reintegrated ilmenite was not in equilibrium with the orthopyroxene at the peak of metamorphism (Fig. 10b), and anomalous pressures are calculated from Sirf using reintegrated compositions of ilmenite
( $\sim 18 \mathrm{~mol} \%$ hematite) and orthopyroxene from Anovitz (1987). Pressures calculated from Sirf using ilmenite compositions predicted from the $K_{D}$ data, analogous to the previous sample, are also high (Fig. 10b and Table 8). These results suggest that the Sirf equilibria are not suitable for barometry in exposed granulites, particularly for assemblages with complex oxide textures or that contain significant ferric iron.

In contrast the results from the three granulite xenoliths are encouraging and suggest that the Sirf equilibria have potential for geobarometry. Although more applications are needed, the Sirf equilibria may be useful for barometry of rocks that are rich in ilmenite and that have not been significantly affected by post peak-metamorphic processes. For rocks in which ilmenite has been altered, successful barometry will depend on the recovery of ilmenite compositions that represent the peak of metamorphism. The application of Sirf (as well as Grips and Grail) barometry on natural samples is hindered, however, by the failure in many publications to report the presence or composition of accessory minerals such as rutile or ilmenite.

\section{Further work}

Data from this study suggest that errors in $W_{G}^{\mathrm{opx}}$ reported in other studies that are less than $(2 \pm 2 \mathrm{ESD}) \mathrm{kJ} /$ mol are overly optimistic, given errors in measurement of the variables $P-T-X$ and in regression statistics. Our reversals of the Sirf equilibria are some of the most tightly bracketed, yet errors of $(2 \pm 5 \mathrm{ESD}) \mathrm{kJ} / \mathrm{mol}$ are obtained for $W_{G}^{\text {opx }}$. Even if the locus of equilibrium (1) is used as a reference, so that a solution for $W_{G}^{\text {Opx }}$ is obtained from each experiment, errors are \pm 1.5 (2 ESD) $\mathrm{kJ} / \mathrm{mol}$. A more accurate determination of $a / X$ relations in orthopyroxene will require many more experiments that are tightly bracketed in systems that involve binary iron-magnesium orthopyroxene and for which the pure end-members can be experimentally located.

Addition of the $\mathrm{CaO}$ component to the Sirf 'system' ( $\mathrm{FeO}-\mathrm{MgO}-\mathrm{SiO}_{2}-\mathrm{TiO}_{2}$ ) permits two equilibria to be calculated for use in thermobarometry of clinopyroxene + rutile assemblages

Ferrosilite + Titanite $=$ Hedenbergite + Rutile

$\mathrm{FeSiO}_{3}+\mathrm{CaTiSiO}_{5}=\mathrm{CaFeSi}_{2} \mathrm{O}_{6}+\mathrm{TiO}_{2}$

and

Hedenbergite + Rutile $=$ Ilmenite + Quartz + Titanite

$\mathrm{CaFeSi}_{2} \mathrm{O}_{6}+2 \mathrm{TiO}_{2}=\mathrm{FeTiO}_{3}+\mathrm{SiO}_{2}+\mathrm{CaTiSiO}_{5}$

derived by combining equilibria (5) and (1). Equilibrium (6) is metastable for reasons analogous to those for equilibrium (1). Equilibrium (5) is also metastable with respect to the coesite equivalent of equilibrium (6).

The following garnet-bearing equilibrium

Almandine + Grossular + Rutile

$2 \mathrm{Fe}_{3} \mathrm{Al}_{2} \mathrm{Si}_{3} \mathrm{O}_{12}+\mathrm{Ca}_{3} \mathrm{Al}_{2} \mathrm{Si}_{3} \mathrm{O}_{12}+3 \mathrm{TiO}_{2}$

$=$ Anorthite + Ferrosilite + Ilmenite

$=3 \mathrm{CaAl}_{2} \mathrm{Si}_{2} \mathrm{O}_{8}+3 \mathrm{FeSiO}_{3}+3 \mathrm{FeTiO}_{3}$ 
is derived by combining equilibrium (1) with Gafs. It is located between 10 and $20 \mathrm{kbar}$ at $700-1100^{\circ} \mathrm{C}$ (Berman 1990,1991$)$ and is metastable with respect to Grips (Bohlen and Liotta 1986) and Gafs (e.g., Bohlen et al. 1983 a). Equilibrium (7) may be useful for thermobarometry of mafic granulites that lack quartz if the effects of $\mathrm{Ca}$ and $\mathrm{Al}$ can be accounted for in mixing relations of orthopyroxene. Mukhopadhyay et al. (1992) formulated a barometer based on a clinopyroxene equivalent to equilibrium (7) and obtained reasonable estimates of pressure for quartz-absent granulites from several terranes with their barometer.

Acknowledgements. This research was supported by National Science Foundation Grants EAR 89- and 91-017772 to E.J.E., the Deep Continental Studies Program of the Usgs, the Geological Society of America, and the Scott Turner Fund of the University of Michigan. The authors thank the following for providing reviews of the manuscript: T. Boundy, R.A. Lange, C. Paslick and M.A. Rathmell. Critical reviews by G.K. Czamanske, J.O. Eckert, A.M. Koziol and D.H. Lindsley improved the clarity of the manuscript. J.L.H. thanks C.E. Manning for help with the piston-cylinder apparatus, D. Palais for help with computer programming, L.C. Calk and R.L. Oscarson for help with the Arl-semq and Sem, A.D. Goldstein and W.B. Hankins for assistance with machining and maintenance of the high-pressure equipment, and A.M. Koziol for providing synthetic $\mathrm{Ilm}_{92} \mathrm{Gk}_{8}$. We thank the following for providing unpublished material: L.M. Anovitz for sample ROS-83C-16 and D.H. Lindsley for the Quilf program. Helpful discussions were provided by M. Ghiorso, R.A. Lange, D.H. Lindsley, C.E. Manning, D. Palais, C. Paslick and M.A. Rathmell.

\section{References}

Akaogi M, Kusaba K, Susaki J, Yagi T, Matsui M, Kikegawa $\mathrm{T}$, Yusa H, Ito E (1992) High-pressure high-temperature stability of $\alpha \mathrm{PbO}_{2}$-type $\mathrm{TiO}_{2}$ and $\mathrm{MgSiO}_{3}$ majorite: calorimetric and in situ X-ray diffraction studies. In: Syono $\mathrm{Y}$, Manghnani $\mathrm{MH}$ (eds) High-pressure research: application to earth and planetary sciences. Terra Scientific/American Geophysical Union, Tokyo/ Washington DC (in press)

Akimoto S, Fujisawa $\mathrm{H}$, Katsura $\mathrm{T}$ (1964) Synthesis of $\mathrm{FeSiO}_{3}$ pyroxene (ferrosilite) at high pressures. Proc Jpn Acad 40:272275

Andersen DJ, Lindsley DH (1988) Internally consistent solution models for Fe-Mg-Mn-Ti oxides: Fe-Ti oxides. Am Mineral 73:714-726

Andersen DJ, Bishop FC, Lindsley DH (1991) Internally consistent solution models for Fe-Mg-Mn-Ti oxides: Fe-Mg-Ti oxides and olivine. Am Mineral 76:427-444

Andersen DJ, Lindsley DH, Davidson PM (1992) QUILF: a PAS$\mathrm{CAL}$ program to assess equilibria among $\mathrm{Fe}-\mathrm{Mg}$-Ti oxides, pyroxenes, olivine and quartz. Comput and Geosci (in press)

Anovitz LM (1987) Pressure-temperature-time constraints on the metamorphism of the Grenville Province, Ontario. $\mathrm{PhD}$ thesis, Univ Michigan

Anovitz LM, Essene EJ (1987) Compatibility of geobarometers in the system $\mathrm{CaO}-\mathrm{FeO}-\mathrm{Al}_{2} \mathrm{O}_{3}-\mathrm{SiO}_{2}-\mathrm{TiO}_{2}$ : implications for garnet mixing models. J Geol 95:633-645

Anovitz LM, Essene EJ (1990) Thermobarometry and pressuretemperature paths in the Grenville Province of Ontario. J Petrol 31:197-241

Anovitz LM, Treiman AH, Essene EJ, Hemingway BS, Westrum EF Jr, Wall VJ, Burriel R, Bohlen SR (1985) The heat capacity of ilmenite and phase equilibria in the system Fe-Ti-O. Geochim Cosmochim Acta 49:2027-2040

Anovitz LM, Essene EJ, Dunham WR (1988) Order-disorder experiments on orthopyroxenes: implications for the orthopyroxene speedometer. Am Mineral 73:1060-1073
Bence AE, Albee AL (1968) Empirical correction factors for the electron microanalysis of silicates and oxides. J Geol 76:382403

Berman $R G(1988)$ Internally consistent thermodynamic data for stoichiometric minerals in the system $\mathrm{Na}_{2} \mathrm{O}-\mathrm{K}_{2} \mathrm{O}-\mathrm{CaO}-\mathrm{MgO}-$ $\mathrm{FeO}-\mathrm{Fe}_{2} \mathrm{O}_{3}-\mathrm{Al}_{2} \mathrm{O}_{3}-\mathrm{SiO}_{2}-\mathrm{TiO}_{2}-\mathrm{H}_{2} \mathrm{O}-\mathrm{CO}_{2}$. J Petrol 29:445-522

Berman RG (1990) Mixing properties of Ca-Mg-Fe-Mn garnets. Am Mineral 75:328-344

Berman RG (1991) Thermobarometry using multi-equilibrium calculations: a new technique with petrologic applications. Can Mineral 29:833-855

Besancon JR (1981) Rate of cation ordering in orthopyroxenes. Am Mineral 66:965-973

Bishop FC (1980) The distribution of $\mathrm{Fe}^{2+}$ and $\mathrm{Mg}$ between coexisting ilmenite and pyroxene with applications to geothermometry. Am J Sci 280:46-77

Bohlen SR (1984) Equilibria for precise pressure calibration and a frictionless furnace assembly for the piston-cylinder apparatus. Neues Jahrb Mineral Monatsh 9:404-412

Bohlen SR, Boettcher AL (1981) Experimental investigations and geological applications of orthopyroxene geobarometry. Am Mineral 66:951-964

Bohlen SR, Boettcher AL (1982) The quartz=coesite transformation: a precise determination and the effects of other components. J Geophys Res 87:7073-7078

Bohlen SR, Liotta JJ (1986) A barometer for garnet amphibolites and garnet granulites. J Petrol 27:1025-1034

Bohlen SR, Wall VJ, Boettcher AL (1983 a) Experimental investigation and application of garnet granulite equilibria. Contrib Mineral Petrol 83:52-61

Bohlen SR, Wall VJ, Boettcher AL (1983b) Experimental investigations and geological applications of equilibria in the system $\mathrm{FeO}-\mathrm{TiO}_{2}-\mathrm{Al}_{2} \mathrm{O}_{3}-\mathrm{SiO}_{2}-\mathrm{H}_{2} \mathrm{O}$. Am Mineral 68:1049-1058

Chatillon-Colinet C, Newton RC, Perkins D III, Kleppa OJ (1983) Thermochemistry of $\left(\mathrm{Fe}^{2+}, \mathrm{Mg}\right) \mathrm{SiO}_{3}$ orthopyroxene. Geochim Cosmochim Acta 47:1597-1603

Clark SP (1959) Effect of pressure on the melting points of eight alkali halides. J Chem Phys 31:1526-1531

Cohen LH, Klement W Jr (1967) High-low quartz inversion: determination to 35 kilobars. J Geophys Res 72:4545-4551

Coleman RG (1961) Jadeite deposits of the Clear Creek area, New Idria District, San Benito Country, California. J Petrol 2:209247

Domeneghetti MC, Steffen G (1992) M1, M2 site populations and distortion parameters in synthetic $\mathrm{Mg}-\mathrm{Fe}$ orthopyroxenes from Mössbauer spectra and X-ray structure refinements. Phys Chem Mineral 19:298-306

Eckert JO Jr, Bohlen SR (1992) Reversed experimental determinations of the $\mathrm{Mg}-\mathrm{Fe}$ exchange equilibrium in $\mathrm{Fe}$-rich garnetorthopyroxene pairs. Eos Trans Am Geophys Union 73:608

Eckert JO Jr, Newton RC, Kleppa OJ (1991) The $\Delta \mathrm{H}$ of reaction and recalibration of garnet-pyroxene-plagioclase-quartz geobarometers in the CMAS system by solution calorimetry. Am Mineral 76:148-160

Ellis DJ, Green DH (1979) An experimental study of the effect of $\mathrm{Ca}$ upon garnet-clinopyroxene $\mathrm{Fe}-\mathrm{Mg}$ exchange equilibria. Contrib Mineral Petrol 71:13-22

Eugster HP (1957) Heterogeneous reactions involving oxidation and reduction at high pressures and temperatures. J Chem Phys 26:1760-1761

Frost BR, Lindsley DH (1992) Equilibria among Fe-Ti oxides, pyroxenes, olivine, and quartz. II. Application. Am Mineral 77:1004-1020

Frost BR, Lindsley DH, Andersen DJ (1988) Fe-Ti oxide-silicate equilibria: assemblages with fayalitic olivine. Am Mineral $73: 727-740$

Ganguly $\mathbf{J}(1982) \mathrm{Mg}-\mathrm{Fe}$ order-disorder in ferromagnesian silicate. II. Thermodynamics, kinetics and geological implications. In: Saxena SK (ed) Advances in physical geochemistry, vol 2. Springer, Berlin Heidelberg New York, pp 58-99

Ghiorso MS (1990) Thermodynamic properties of hematite-ilmenite-geikielite solid solutions. Contrib Mineral Petrol 104:645667 
Ghiorso MS, Sack RO (1991) Thermochemistry of the oxide minerals. In: Lindsley DH (ed) Oxide minerals: petrologic and magnetic significance. Reviews in mineralogy 25, Mineral Soc Am Washington $\mathrm{DC}$, pp 221-264

Goldich SS, Ingamells CO, Suhr NH, Anderson DH (1967) Analyses of silicate rock and mineral standards. Can J Earth Sci 4:74-755

Griffin WL, Jensen BB, Misra SN (1971) Anomalously elongated rutile in eclogite-facies pyroxene and garnet. Nor Geol Tidss-r $51: 177-185$

Haggerty SE, Lindsley DH (1969) Stability of the pseudobrookite $\left(\mathrm{Fe}_{2} \mathrm{TiO}_{5}\right)$-ferropseudobrookite $\left(\mathrm{FeTi}_{2} \mathrm{O}_{5}\right)$ series. Carnegie Inst Washington Yearb 68:247-249

Harley SL (1984) An experimental study of the partitioning of Fe and $\mathrm{Mg}$ between garnet and orthopyroxene. Contrib Mineral Petrol 86:359-373

Haselton HT, Hovis GL, Hemingway BS, Robie RA (1983) Calorimetric investigation of the excess entropy of mixing in analbitesanidine solid-solutions: lack of evidence for $\mathrm{Na}, \mathrm{K}$ short-range order and implications for two-feldspar thermometry. Am Mineral 68:398-413

Hawthorne FC, Ito J (1977) Synthesis and crystal-structure refinement of transition-metal orthopyroxenes. I. Orthoenstatite and $(\mathrm{Mg}, \mathrm{Mn}, \mathrm{Co}$ ) orthopyroxene. Can Mineral 15:321-328

Hayob JL, Essene EJ, Ruiz J, Ortega-Gutierrez F, Aranda-Gomez JJ (1989) Young high-temperature granulites from the base of the crust in central Mexico. Nature 342:265-268

Irving AJ (1974) Geochemical and high pressure experimental studies of garnet pyroxenite and pyroxene granulite xenoliths from the Delegate basaltic pipes, Australia. J Petrol 15:1-40

Jarosewich E, Nelen JA, Norberg JA (1980) Reference samples for electron microprobe analysis. Geostandards News1 4:43-47

Kitayama K (1970) Activity measurements in orthosilicate and metasilicate solid solutions. II. $\mathrm{MgSiO}_{3}-\mathrm{FeSiO}_{3}$ at 1154,1204 , and $1250^{\circ}$ C. Bull Chem Soc Jpn 43:1390-1393

Kitayama K, Katsura T (1968) Activity measurements in orthosilicate and metasilicate solid solution. I. $\mathrm{Mg}_{2} \mathrm{SiO}_{4}-\mathrm{Fe}_{2} \mathrm{SiO}_{4}$ and $\mathrm{MgSiO}_{3}-\mathrm{FeSiO}_{3}$ at $1204^{\circ} \mathrm{C}$. Bull Chem Soc Jpn 41:1146-1151

Koch-Müller M, Cemič L, Langer K (1992) Experimental and thermodynamic study of $\mathrm{Fe}-\mathrm{Mg}$ exchange between olivine and orthopyroxene in the system $\mathrm{MgO}-\mathrm{FeO}-\mathrm{SiO}_{2}$. Eur J Mineral 4:115-135

Lee HJ, Ganguly J (1988) Equilibrium compositions of coexisting garnet and orthopyroxene: experimental determinations in the system $\mathrm{FeO}-\mathrm{MgO}-\mathrm{Al}_{2} \mathrm{O}_{3}-\mathrm{SiO}_{2}$ and applications. J Petrol 29:93113

Li G, Cao R (1982) On the oxygen partial pressure and activity of $\mathrm{FeTiO}_{3}-\mathrm{MgTiO}_{3}$ solid solution system (in Chinese). Acta Metall Sinica 18:371-377

Lindsley DH (1983) Pyroxene thermometry. Am Mineral 68:477493

Lindsley DH, Nekvasil H (1989) A ternary feldspar model for all reasons. Eos Trans Am Geophys Union 70:506

Lindsley DH, Kesson SE, Hartzmann MJ, Cushman MK (1974) The stability of armalcolite: experimental studies in the system Mg-Fe-Ti-O. Proc Lunar Sci Conf 5th, Geochim Cosmochim Acta Suppl 5:521-534

Matsui Y, Syono Y, Akimoto S, Kitayama K (1968) Unit cell dimensions of some synthetic orthopyroxene group solid solutions. Geochem J 2:61-70

Molin GM, Saxena SK, Brizi E (1991) Iron-magnesium order-disorder in an orthopyroxene crystal from the Johnstown meteorite. Earth Planet Sci Lett 105:260-265

\section{Note added in proof}

Single-crystal X-ray diffraction data of Yang and Ghose (1993, submitted to Phys Chem Mineral) are consistent with the assumption that the volume of mixing for $(\mathrm{Fe}, \mathrm{Mg}) \mathrm{SiO}_{3}$ orthopyroxene is linear at $298-1200 \mathrm{~K}$ at 1 bar.
Moore A (1968) Rutile exsolution in orthopyroxene. Contrib Mineral Petrol 17:233-236

Morimoto N, Koto K (1969) The crystal structure of orthoenstatite. Z Kristallogr 129:65-83

Mukhopadhyay A, Bhattacharya A, Mohanty L (1992) Geobarometers involving clinopyroxene, garnet, plagio clase, ilmenite, rutile, sphene and quartz: estimation of pressure in quartz-absent assemblages. Contrib Mineral Petrol 110:346-354

Nafziger RH, Muan A (1967) Equilibrium phase compositions and thermodynamic properties of olivines and pyroxenes in the system $\mathrm{MgO}-\mathrm{FeO}-\mathrm{SiO}_{2}$. Am Mineral 52:1364-1385

Navrotsky A (1971) The intractystalline cation distribution and the thermodynamics of solid solution formation in the system $\mathrm{FeSiO}_{3}-\mathrm{MgSiO}_{3}$. Am Mineral 56:201-211

Newton RC, Perkins D III (1982) Thermodynamic calibration of geobarometers based on the assemblage garnet-plagioclase-orthopyroxene-clinopyroxene-quartz. Am Mineral 67:203-222

Sack RO, Ghiorso MS (1989) Importance of considerations of mixing properties in establishing an internally consistent data base: thermochemistry of minerals in the system $\mathrm{Mg}_{2} \mathrm{SiO}_{4}-\mathrm{Fe}_{2} \mathrm{SiO}_{4}-\mathrm{SiO}_{2}$. Contrib Mineral Petrol 102:41-68

Saxena SK, Ghose S (1971) $\mathrm{Mg}^{2+}-\mathrm{Fe}^{2+}$ order-disorder and the thermodynamics of the orthopyroxene crystalline solution. Am Mineral 56:532-559

Saxena SK, Domeneghetti GM, Molin GM, Tazzoli V (1989) X-ray diffraction study of $\mathrm{Fe}^{2+}-\mathrm{Mg}$ order-disorder in orthopyroxene. Some kinetic results. Phys Chem Mineral 16:421-427

Sen SK, Bhattacharya A (1984) An orthopyroxene-garnet thermometer and its application to the Madras charnockites. Contrib Mineral Petrol 88:64-71

Sharma KC, Agrawal RD, Kapoor ML (1987) Determination of thermodynamic properties of $(\mathrm{Fe}, \mathrm{Mg}$ )-pyroxenes at $1000 \mathrm{~K}$ by the emf method. Earth Planet Sci Lett 85:302-310

Shi P, Saxena SK, Sundman B (1992) Sublattice solid solution mod$\mathrm{el}$ and its application to orthopyroxene $(\mathrm{Mg}, \mathrm{Fe})_{2} \mathrm{Si}_{2} \mathrm{O}_{6}$. Phys Chem Mineral 18:393-405

Skogby H (1992) Order-disorder kinetics in orthopyroxenes of ophiolite origin. Contrib Mineral Petrol 109:471-478

Smith JV, Stephenson DA, Howie RA, Hey MH (1969) Relations between cell dimensions, chemical composition and site preference of orthopyroxene. Mineral Mag 37:90-114

Stephenson DA, Sclar CB, Smith JV (1966) Unit-cell volumes of synthetic orthoenstatite and low clinoenstatite. Mineral Mag 35:838-846

Sueno S, Cameron M, Prewitt CT (1976) Orthoferrosilite: hightemperature crystal chemistry. Am Mineral 61:38-53

Thompson JB Jr (1967) Thermodynamic properties of simple solutions. In: Abelson PH (ed) Researches in geochemistry 2, Wiley, New York, pp 340-361

Turnock AC, Lindsley DH, Grover JE (1973) Synthesis and unit cell parameters of $\mathrm{Ca}-\mathrm{Mg}-\mathrm{Fe}$ pyroxenes. Am Mineral 58:50-59

Virgo D, Hafner SS (1969) $\mathrm{Fe}^{2+}, \mathrm{Mg}$ order-disorder in heated orthopyroxenes. Mineral Soc Am Spec Pap 2:67-81

von Seckendorff V, O'Neill HStC (1993) An experimental study of $\mathrm{Fe}-\mathrm{Mg}$ partitioning between olivine and orthopyroxene at 1173,1273 and $1243 \mathrm{~K}$ and $1.6 \mathrm{GPa}$. Contrib Mineral Petrol 113:196-207

Wiser NM, Wood BJ (1991) Experimental determination of activities in $\mathrm{Fe}-\mathrm{Mg}$ olivine at $1400 \mathrm{~K}$. Contrib Mineral Petrol 108:146-153

Yoder HS Jr, Sahama TG (1957) Olivine X-ray determinative curve. Am Mineral 42:475-491

Editorial responsibility: T. Grove 